\title{
CARACTERIZAÇÃO DE LINHAGENS MUTANTES DE ARROZ DE SEQUEIRO OBTIDAS COM UTILIZAÇÃO DA AZIDA SÓDICA ( $\left.\mathrm{NaN}_{3}\right)$
}

\author{
EDSON FERREIRA DA SILVA \\ BIÓLOGO
}

Orientador: Prof. Dr. AKIHIKO ANDO

Dissertação apresentada à Escola Superior de Agricultura "Luiz de Queiroz" da Universidade de São Paulo para obtenção do título de Mestre em Agronomia, Área de Concentração: Genética e Melhoramento de Plantas.

PIRACICABA

Estado de São Paulo - Brasil

Novembro - 1994 
Dados Internacionais de Catalogação na Publicação (CIP)

DIVISÃo DE BIBLIOTECA E DOCUMENTAÇÃO - Campus "Luiz de Queiroz"/USP

Silva, Edson Ferreira da

Caracterizaçāo de linhagens mutantes de arroz de sequeiro obtidas com utilizaçāo da azida sódia $\left(\mathrm{NaN}_{3}\right) /$ Edson Ferreira da Silva. - - Piracicaba, 1997. 4 í

$$
578
$$

Dissertaçāo (mestrado) - - Escola Superior de Agricultura Luiz de Queiroz, 1997.? Bibliografia.

1. Arroz de sequeiro 2. Azida sódia 3. Linhagem vegetal 4. Melhoramento genético vegetal 5 . Nitrogênio I. Titulo

CDD 633.18 


\section{CARACTERIZAÇÃO DE LINHAGENS MUTANTES DE ARROZ DE SEQUEIRO OBTIDAS COM UTILIZAÇÃO \\ DA AZIDA SÓDICA ( $\left.\mathrm{NaN}_{3}\right)$}

EDSON FERREIRA DA SILVA

Aprovada em: 27-01-95

Comissão julgadora:

Prof. Dr. Akihiko Ando

Prof. Dr. Natal Antônio Vello

Dr. Otávio Tisselli Filho
ESALQ/USP

ESALQ/USP

IAC

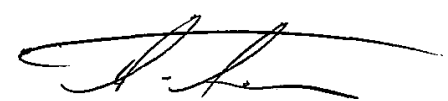

Prof. AKIHIKO ANDO

- Orientador - 
À minha filha Gabriela DEDICO 
À minha mãe (in memorian), ao meu pai e aos meus familiares 


\section{AGRADECIMENTOS}

Expressamos os nossos agradecimentos a todos aqueles que contribuíram para a realização deste trabalho, de uma maneira especial, às seguintes pessoas e entidades:

Ao Prof. Dr. Akihiko Ando, pela orientação, estímulo e atenção sempre demonstradas.

Aos Pesquisadores do Programa de Melhoramento do Arroz, do Instituto Agronômico: Drs. Luiz Ernesto Azzini, Otavio Tisselli Filho e Cândido Ricardo Bastos, pelas colaborações prestadas durante a condução de ensaios no Centro Experimental de Campinas, incentivos e valiosas sugestões.

Aos Professores do Departamento de Genética da ESALQ pelos ensinamentos e atenção.

Aos Funcionários e colegas do curso do Departamento de Genética pela prestatividade e coleguismo.

À Margarete Aparecida das Chagas, pela colaboração na digitação e impressão.

Ao Pesquisador Dr. Luiz Fernandes Razera e ao Engenheiro Agrônomo Marcelo Ticelli pelo incentivo e prestatividade.

Ao Conselho Nacional de Desenvolvimento Científico e Tecnológico (CNPq) pela concessão de bolsa para realização do curso.

Ao Instituto Agronômico do Estado de São Paulo pela oportunidade fornecida para realização do curso de pós-graduação.

A Todos aqueles que, de alguma forma, contribuíram para que este trabalho pudesse ser realizado. 


\section{ÍNDICE}

\section{Página}

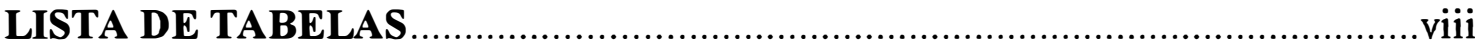

RESUMO

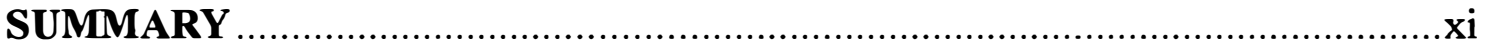

1. INTRODUÇÃO

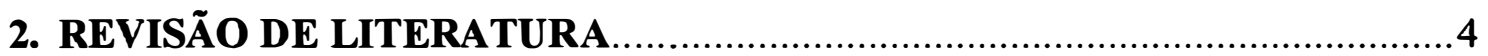

2.l. Características fenológicas e fisiológicas da planta de arroz, com ênfase à avaliação e caracterização de cultivares ........................................... 4

2.2. Alguns resultados obtidos pelo emprego de agentes mutagênícos, no

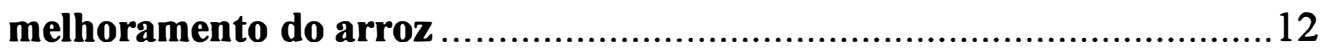

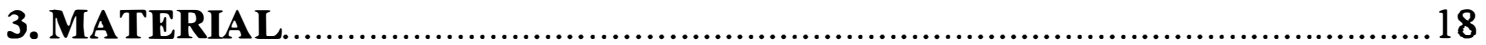

4. MÉTODO

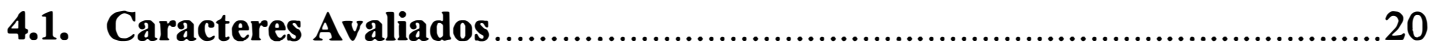

4.1.1. Número de dias até o florescimento e até a maturação.................20

4.1.2. Número de perfilhos por planta...............................................21

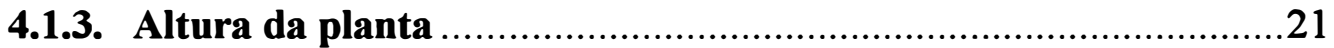

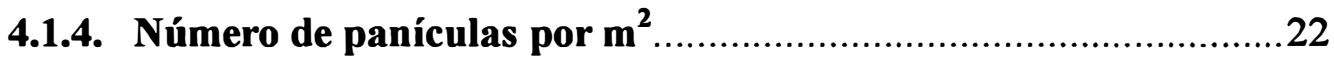

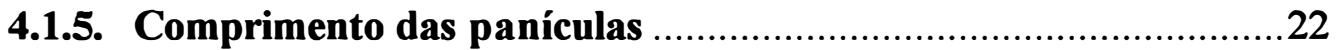

4.1.6. Número de espiguetas granadas por panícula ……....................22

4.1.7. Porcentagem de espiguetas estéreis por panícula .........................23

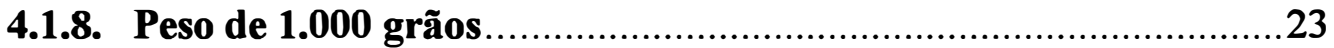

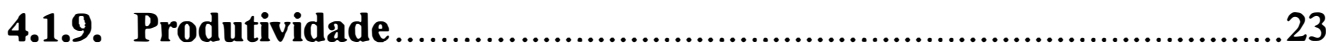

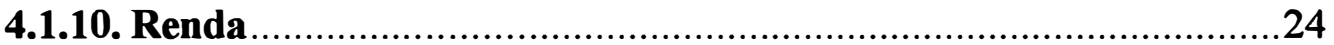

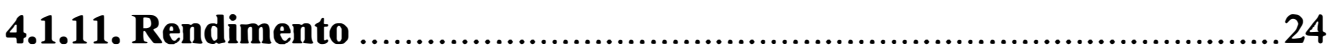

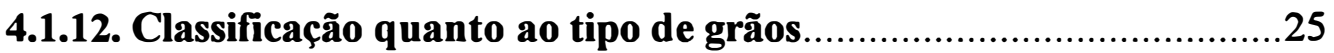

4.1.13. Comprimento, largura e espessura do grão ……......................25

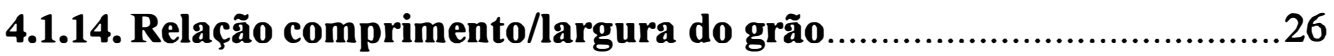

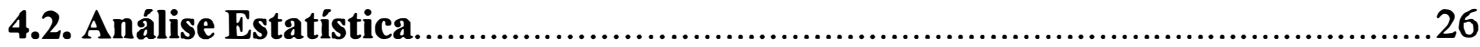


5.1. Quadrados médios, teste F e coeficiente de variação (CV\%), médias, variância coeficiente de variação genética e herdabilidade.

5.2. Número de dias até o florescimento e até a maturação ……...................29

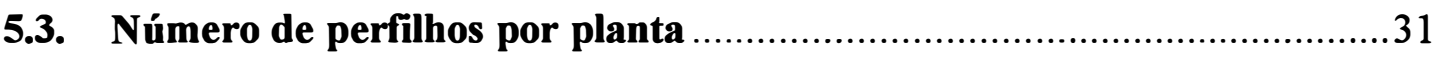

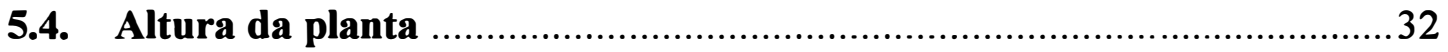

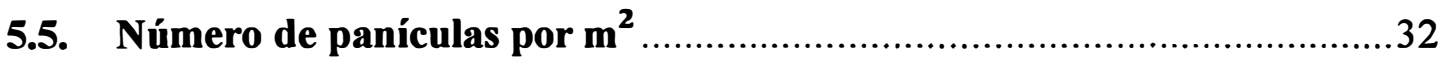

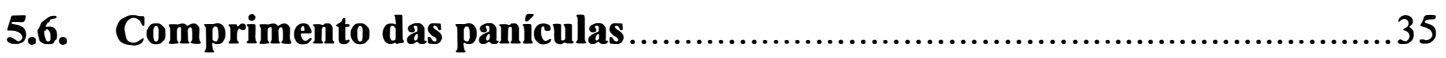

5.7. Número de espiguetas granadas por panícula ……….............................35

5.8. Porcentagem de espiguetas estéreis por panícula ...................................38

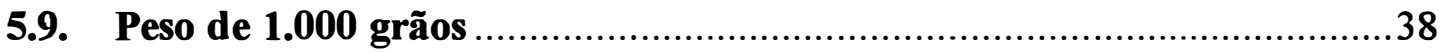

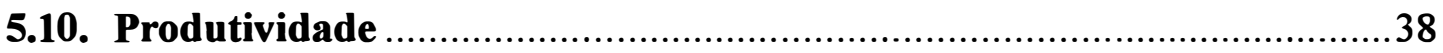

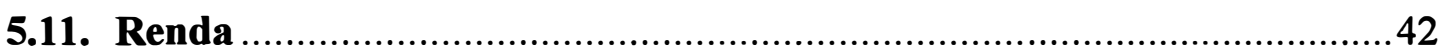

5.12. Rendimento

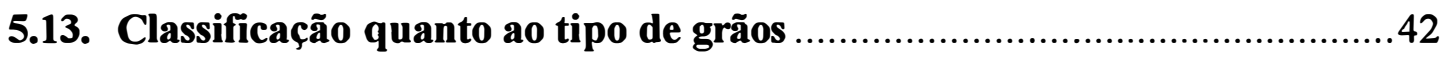

5.14. Comprimento, largura e espessura dos grãos beneficiados e polidos ......46

5.15. Relação comprimento/largura dos grãos beneficiados e polidos ……......46

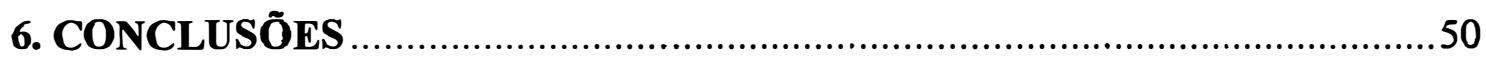

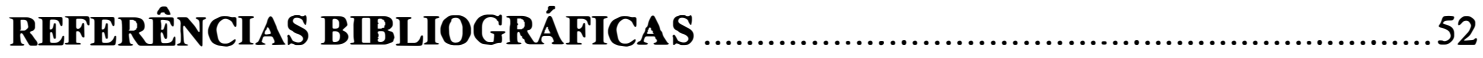




\section{LISTA DE TABELAS}

Página

Tabela 1. Quadrados médios, teste $\mathrm{F}$, coeficiente de variação (CV\%), médias variância, coeficiente de variação genética e herdabilidade. 30

Tabela 2. Médias ordenadas do número de perfilhos por planta 31

Tabela 3. Médias ordenadas da altura das plantas $(\mathrm{cm})$ .33

Tabela 4. Médias ordenadas do número de panículas por $\mathrm{m}^{2}$. .34

Tabela 5. Médias ordenadas do comprimento das panículas (em $\mathrm{cm}$ do primeiro nó até a extremidade da última espigueta).

Tabela 6. Médias ordenadas do número de grãos por panícula .37

Tabela 7. Médias ordenadas da porcentagem de espiguetas estéreis por panícula ....39

Tabela 8. Médias ordenadas do peso de 1.000 grãos 40

Tabela 9. Médias ordenadas da produtividade de grãos $(\mathrm{kg} / \mathrm{ha})$

Tabela 10. Médias ordenadas da renda, avaliada a partir de 100 gramas de grão em casca (valor em gramas dos grãos inteiros e quebrados beneficiado).. 43

Tabela 11. Médias ordenadas do rendimento, avaliado a partir de 100 grãos em cascas (valor em gramas de grãos inteiros após o beneficiamento)

Tabela 12. Médias ordenadas da largura do grão beneficiado e polido (mm) .45

Tabela 13. Médias ordenadas do comprimento dos grãos beneficiados e polidos $(\mathrm{mm})$

Tabela 14. Médias ordenadas da espessura dos grãos (mm)

Tabela 15. Médias ordenadas da relação comprimento/largura dos grãos (mm)

Tabela 16. Apresentação sintética das médias das características estudadas, discriminados pelo teste de Tukey em relação Dourado Precoce 


\section{CARACTERIZAÇÃO DE LINHAGENS MUTANTES DE ARROZ DE SEQUEIRO OBTIDAS COM UTILIZAÇÃO DA AZIDA SÓDICA ( $\left.\mathrm{NaN}_{3}\right)$}

Autor: EDSON FERREIRA DA SILVA

Orientador: PROF. DR. AKIHIIKO ANDO

\section{RESUMO}

O presente trabalho teve por objetivo avaliar características fenológicas e fisiológicas que contribuem para o aumento da produtividade e melhoria da qualidade do grão, em 14 linhagens mutantes selecionadas de arroz de sequeiro (Oryza sativa L.), obtidas a partir de sementes do cultivar Dourado Precoce, tratadas com o mutagênico químico azida sódica $\left(\mathrm{NaN}_{3}\right)$. Para tanto, os mutantes foram dispostos em experimento de caracterização utilizando-se a variedade original Dourado Precoce e IAC 201 como testemunhas.

O experimento foi realizado no Centro Experimental de Campinas do Instituto Agronômico, São Paulo, Brasil no ano agrícola de 1993/94.

O delineamento experimental utilizado foi blocos casualizados com quatro repetições, onde as parcelas experimentais foram constituídas de cinco fileira de quatro metros lineares, espaçadas de 50 centímetros. Foram semeadas 75 sementes por metro linear. Todas as observações foram realizadas nas três fileiras centrais de cada parcela visando minimizar os efeitos de bordadura.

De cada uma das linhagens e cultivares foram avaliados os seguintes caracteres: número de dias até o florescimento e até a maturação, número de perfilhos por planta, altura das plantas, número de panículas por $\mathrm{m}^{2}$, comprimento das panículas, número de grãos por panícula, porcentagem de espiguetas estéreis por panícula, peso de 1.000 grãos, produtividade, renda, rendimento, comprimento, largura e espessura do grão beneficiado e polido e relação comprimento/largura do grão. Para estes caracteres foram 
estimados os parâmetros de variância genética $\left(\hat{\sigma}_{\mathrm{g}}^{2}\right)$ ), coeficiente de variação genética $(\mathrm{CVg})$ e herdabilidade $\left(\mathrm{h}^{2}{ }_{\mathrm{a}}\right)$.

A análise dos dados e interpretação dos resultados permitiram concluir que:

a) Dez linhagens testadas diferem do cultivar original pelo menos em um dos caracteres estudados

b) Dos caracteres avaliados, não houve diferença significativa entre os tratamentos para número de dias até o florescimento e até a maturação, renda, rendimento, e comprimento do grão beneficiado e polido.

c) Entre os dez mutantes que apresentaram características alteradas, o mutuante sete mostrou-se como o mais promissor pela redução no comprimento do colmo, aumento do número de perfilhos, e por manter o comprimento da panícula e produtividade em relação à variedade original Dourado Precoce. 


\title{
CHACTERIZATION OF UPLAND RICE MUTANT LINES \\ OBTAINED BY TREATMENT WITH \\ SODIUM AZIDE $\left(\mathrm{NaN}_{3}\right)$
}

\author{
Author: EDSON FERREIRA DA SILVA \\ Adviser: PROF. DR. AKIHIKO ANDO
}

\section{SUMMARY}

The objective of the present research was to evaluate fourteen selected mutant lines of upland rice (Oryza sativa.L.) as to phenological and physiological characteristics related to high grain yield and grain quality. These mutant lines were originated from seeds of the variety Dourado Precoce treated with the chemical mutagen sodium azide $\left(\mathrm{NaN}_{3}\right)$.

For this purpose, the mutant lines were grown in trial for caracterization with the original variety Dourado and IAC 201, both as the controls

The experiment was carried out in Experimental Center of Agronomic Institute, the State of São Paulo, Brazil, during the period of 1993/1994, utilizing randomized complete block design with four replications. Each experimental plot consisted of five rows, four meters long and spaced $50 \mathrm{~cm}$, with 75 seeds per meter sown in line.

The following characteristics were evaluated: number of days to flowering and to grain maturation, tiller number, plant height, panicle number per $\mathrm{m}^{2}$, panicle length, grain number per panicle, percentage of sterile spikelet per panicle, weight of 1000 unhulled grain, yield of hulled and polished grains, yield of polished unbroken grains, length, width and thickness of the peeled and polished grains, length/width relation of polished grain. Gnetic variance $\left(\hat{\sigma}_{\mathrm{g}}^{2}\right)$, genetic variation coefficiet $(\mathrm{CVg})$ and heritability $\left(h^{2}\right)$ were estimated for these characters.

The data analysis and interpretation of the results obtained allowed to conclude that; 
a) Ten of the fourteen lines tested differed from the original variety, at least in one of the characters studied.

b) No difference was observed among selected lines regarding number of days to flowering and to maturation, yield of hulled and polished grains, yield of polished unbroken grains and length of the peeled and polished grains.

c) Among ten mutant lines with altered characters, the mutant number seven showed to be the most promising for reduced culm length, and high tiller number, maintaining same panicle length and same grain yield as the original variety Dourado Precoce. 


\section{INTRODUÇÃO}

O arroz (Oryza sativa L.) ocupa posição de destaque entre os principais cereais cultivados, sendo um dos alimentos mais consumidos pela população humana, principalmente pelos povos asiáticos e sul americanos.

Em área plantada, o cultivo de arroz é superado apenas pelo trigo e em rendimento de grãos, é apenas pelo milho (FORNASIERI FILHO \& FORNASIERI, 1993). O arroz, assim como os demais cereais, representa uma importante fonte de carboidratos na alimentação humana. Embora não seja tão rico em proteína quanto o trigo ou mesmo o milho, o arroz é mais rico que esses cereais na lisina, treonina e triptofano, o que faz do arroz uma fonte de grande valor nutritivo (NANDA \& COFFMAN, 1978; EGGUM, 1979)

No Brasil, o arroz constitui-se no componente essencial da dieta básica da população, contribuindo com $17,9 \%$ das proteínas ingeridas e $24,2 \%$ das calorias (FORNASIERI FILHO \& FORNASIERI, 1993).

O cultivo se dá em todo território nacional, concentrando-se principalmente nas regiões centro-oeste, sudeste e sul. São predominantes quatro sistemas principais de cultivo: a) arroz inundado (com irrigação controlada); b) arroz de 
várzea úmida (sem irrigação controlada); c) arroz de sequeiro e d) arroz de sequeiro favorecido (com irrigação suplementar). Para cada um desses sistemas, a EMBRAPA e o IAC desenvolvem programas de melhoramento (RANGEL, 1990).

A utilização de variedades melhoradas, mais adaptadas às nossas condições de cultivo, é um dos fatores que podem aumentar a produtividade da cultura do arroz, bem como a qualidade do produto.

Cabe aos programas de melhoramento desenvolver genótipos que façam melhor uso dos nutrientes e da energia solar no menor período, possibilitando uma produção máxima econômica por unidade de área.

A preocupação em se obter variedades de arroz com um tipo de planta ideal, quanto à altura, tipo e disposição das folhas, iniciou-se na década de 1960, quando estudos de fisiologia vegetal demonstraram que diferenças morfológicas das plantas estavam associadas a um melhor aproveitamento dos recursos naturais disponíveis, especialmente luz e nutrientes. Conseqüentemente, plantas mais eficientes no aproveitamento dos recursos disponíveis seriam mais produtivas (JENNINGS, 1964). JENNINGS et al. (1979) sugerem que, no melhoramento do arroz, deve-se priorizar a seleção de plantas com colmos curtos e grossos que são caracteres fortemente determinantes da resistência ao acamamento.

A produtividade média de arroz observada no Brasil de 1978 a 1992 foi de $1,7 \mathrm{~kg} / \mathrm{ha}$ (Anuário Estatístico Brasileiro), isto porque, o sistema de cultivo predominante é o de sequeiro $(73,7 \%)$ que tem uma média de produtividade inferior a 1 t/ha, embora no Estado de São Paulo as médias de produtividade anuais sejam em torno de 1,5 t/ha A baixa produtividade do arroz de sequeiro decorre principalmente da 
incidência de veranicos no período crítico de desenvolvimento da cultura (fase de emborrachamento) e da não disponibilidade de variedades adaptadas para explorar com mais eficiência os recursos naturais das diferentes regiões do cultivo. Neste contexto, o aumento da produtividade brasileira depende da elevação nos patamares de produtividade do arroz de sequeiro, através de variedades adaptadas a este sistema de cultivo.

No campo da mutagênese experimental em plantas, há uma preocupação em se conhecer as alterações provocadas pelos diferentes agentes mutagênicos nas características morfo-fisiológicas das plantas, tentando aproveitar aquelas consideradas como desejáveis, tais como precocidade, plantas de porte baixo, plantas com folhas curtas e eretas, etc. (ANGLADETTE, 1968; ANDO, 1972 e 1973).

O presente trabalho teve por objetivo estudar as características fenológicas e morfológicas que influenciam na produtividade e qualidade do grão, em 14 linhagens mutantes de arroz, selecionadas a partir da variedade Dourado Precoce após tratamento com o mutagênico químico azida sódica. As linhagens mutantes foram comparadas com a variedade original Dourado Precoce e com IAC 201 que é o cultivar de sequeiro de melhor qualidade de grão recomendado para o Estado de São Paulo. 


\section{REVISÃO DE LITERATURA}

A revisão bibliográfica foi direcionada no sentido de se conhecer características fenológicas, morfológicas e fisiológicas da planta do arroz, dando ênfase à avaliação e caracterização de cultivares, bem como alguns resultados obtidos pelo emprego de agentes mutagênicos, no melhoramento do arroz.

\subsection{Características fenológicas e fisiológicas da planta de arroz, com ênfase à avaliação e caracterização de cultivares}

Segundo GERMEK \& BANZATTO (1972), várias características estão ligadas a uma maior produtividade das variedades de arroz, e dentre elas destacamse: maior número de perfilhos ou colmos por planta, maior comprimento e densidade das panículas, resistência ao acamamento e ciclo adequado às condições ambientais.

Ainda, segundo os mesmos autores, atualmente os trabalhos de melhoramento têm tido como objetivo obter melhores tipos de plantas, que permitam 
aplicação de pesadas adubações nitrogenadas. Via de regra, adubações nitrogenadas em altas doses promovem exagerado desenvolvimento das plantas, tornando-as mais sujeitas ao acamamento e incidência de brusone (Pyricularia oryzae Cav.). Portanto, cultivares de porte alto e colmos fracos são inadequadas para essa finalidade. $\mathrm{O}$ objetivo é conseguir cultivares de porte baixo, com $80-90 \mathrm{~cm}$ de altura, colmos fortes e bainhas persistentes, folhas curtas, finas e eretas para maior aproveitamento de luz pelas plantas, grãos longos e vítreos, bom rendimento de engenho e resistência à brusone.

Segundo SOUZA et al. (1972), para avaliação de cultivares de arroz, pode-se observar as seguintes características: altura da planta, perfilhamento útil, ângulo da folha bandeira com a penúltima folha e inserção da panícula. Relatam ainda que os principais caracteres diretamente ligados à altura e à resistência ao acamamento são: comprimento da panícula, número de ramificações por panícula, número de grãos por panícula, número de panículas férteis por ocasião da colheita e peso de 1.000 grãos.

NAVASERO \& TANAKA (1966) e JENNINGS et al. (1979) observaram que os cultivares modernas de arroz (de porte baixo) suportam melhor as altas densidades de plantio, pois nestas, entre outros fatores, o mútuo sombriamente das folhas é menor em relação, aos cultivares de porte alto. Porém, as plantas de porte baixo, segundo os autores, são mais suscetíveis à competição com plantas daninhas. Deve-se considerar ainda que plantas de porte baixo permitem o cultivo em espaçamento mais adensados e/ou sob sistema com irrigação suplementar, que permite elevar a produtividade. 
BLUM (1982) ressalta a importância dos caracteres que evitam a desidratação de plantas, entre os quais destacam-se: folhas estreitas e eretas, menor área foliar da planta, fechamento de estômatos, cerosidade da folha e sistema radicular desenvolvido. Segundo esse autor, de todos os atributos, o comprimento total do sistema radicular por volume de solo é o atributo mais operativo para evitar a desidratação.

Para SILVA (1975), a descrição das características morfológicas e culturais pode ser baseada nos seguintes critérios e classes relativas:

Estatura: altura é determinada pela altura do colmo principal medida desde a base até o nó inferior da panícula. Esta pode ser:

mediana

Comprimento da panícula: a medição da panícula é feita desde o nó inferior desta até a extremidade do último grão. A panícula pode ser: curta menos de $17 \mathrm{~cm}$ mediana de 17 a $22 \mathrm{~cm}$ comprida mais de $22 \mathrm{~cm}$. 
DALRYMPLE (1976) relata que as primeiras cultivares de porte baixo foram lançadas a partir do final da década de 60. Em 1974/75, as mesmas já ocupavam cerca de $26 \%$ da área de plantio da Ásia, isto é, em torno de 31 milhões de hectares. Esse fato dá idéia da aceitação das variedades de porte baixo.

KERSTING et al. (1976) relataram que, no Estado do Rio Grande do Sul, há três grandes grupos de cultivares de arroz, sendo elas: tradicionais, americanas e de porte baixo. As variedades de porte baixo são também conhecidas como variedades de porte moderno. São plantas de colmos fortes e folhas eretas, com as seguintes características: plantas de pequena altura, exigentes em um pequeno controle das plantas daninhas devido a arquitetura da planta que possibilita o adensamento de plantio, alta capacidade de perfilhamento, alta resposta à adubação nitrogenada e irrigação, alta capacidade produtiva, fácil degrana, resistência ao acamamento e certa tolerância à brusone.

SILVA (1976) relata que, visando aumentar a produtividade, os melhoristas objetivam criar cultivares cujas plantas tenham as seguintes características: colmos fortes e porte baixo para aumentar a resistência ao acamamento; folhas eretas que permaneçam verdes até a época de maturação, para garantir melhor nutrição da planta; perfilhos vigorosos para obtenção de maior número de panículas por unidade de área; respostas em produção de grãos a altos níveis de fertilidade do solo, em especial a doses mais altas de adubação nitrogenada; ciclo precoce ou médio, o que irá diminuir o risco da cultura no campo provocado pela instabilidade climática. 
Segundo o relato da EMBRAPA (1977), o ciclo da planta de arroz pode ser dividido em três fases, as quais são: vegetativa (da emergência à iniciação da panícula) ; reprodutiva (da iniciação da panícula à floração) e maturativa (da floração à maturação completa). A duração de cada fase é a seguinte:

fase vegetativa bastante variável

fase reprodutiva cerca de 35 dias

fase maturativa de 25 a 35 dias.

No mesmo relato pode-se observar que o ciclo depende da fase vegetativa, visto que as demais são aproximadamente constantes. Considerando o período entre a emergência e a maturação, cultivares de arroz podem ser classificados em:

precoce até 105 dias

semi-precoce de 106 a 120 dias

médio de 121 a 135 dias

semi-tardio de 136 a 150 dias tardio acima de 150 dias.

Para PEDROSO et al. (1977), o ciclo vegetativo é o tempo expresso em dias da emergência ao florescimento completo. A altura da planta é estimada pela média de 10 plantas competitivas sendo medida da base da planta à extremidade da panícula. $\mathrm{O}$ peso de 1.000 grãos é obtido pela pesagem de grãos inteiros com casca. 
STEINMETZ (1986) enfatiza que o ciclo precoce da cultura do arroz de sequeiro, além de ser importante caráter para diminuir o grau de risco por estresse hídrico, tem importância também no tocante à determinação da época de plantio ou rotação com outras culturas.

No IRRI, os pesquisadores estão empenhados em conseguir variedades que possuam ciclo curto e porte baixo entre outras características (IRRI, 1978). Em 1979, o IRRI possuía um grande número de linhagens que atingiam a maturidade com menos de 100 dias (IRRI, 1979).

CARMONA et al. (1980) procuram, no IRGA, selecionar plantas de porte baixo e precocidade entre outras características.

SILVA et al. (1980) realizaram, no ano agrícola 1979/80, quatro ensaios de produção, na Estação Experimental do Arroz, em Cachoeirinha (RS). Foram feitas as seguintes determinações: rendimento de grãos com $13 \%$ de umidade, ciclo vegetativo (desde a semeadura até florescimento); altura (média de 10 plantas, $\mathrm{em} \mathrm{cm}$ ); esterilidade das espiguetas (média de 10 plantas, em percentagem), entre outras. Confirmando resultados anteriores, os melhores rendimentos foram alcançados por genótipos que possuem tipo de planta com perfilhamento melhorado (porte baixo, alta capacidade de perfilhamento e folhas eretas), contudo nos ensaios preliminares, diversas linhagens desse tipo apresentaram ciclo vegetativo muito longo e grãos de qualidade inferior que devem ser descartadas.

NOLDIN et al. (1981), em ensaios de competição de cultivares e linhagens de arroz irrigado em Santa Catarina, concluíram que, em todos os locais, 
aquelas de porte baixo apresentaram rendimento de grãos superior às tradicionais e às americanas, demonstrando maior potencial de produção. Segundo os autores, os cultivares do grupo tradicional apresentaram intenso acamamento, principalmente na fase de floração e maturação.

PEDROSO \& SILVA (1981), visando introduzir linhagens de arroz de sequeiro para cultivo no Rio Grande do Sul, realizaram ensaios onde procurou-se determinar os cultivares que melhor se comportam nessas condições. Foram avaliadas as seguintes características agronômicas: ciclo vegetativo, estatura das plantas, número de panículas por $\mathrm{m}^{2}$, número de grãos por panícula, peso de 1.000 grãos e rendimento por hectare.

SRINIVAS \& BHASHYAN (1985) observaram que a quebra dos grãos, verificada durante o processo de beneficiamento, que é causada por fissuras e/ou regiões de menor resistência nos grãos diminuiu o rendimento e a qualidade do produto. Tais fissuras e regiões menos resistentes não têm causas bem elucidadas, mas as condições ambientais de umidade, principalmente nas fases de enchimento e maturação de grãos, exercem influência no rendimento, assim como as características varietais.

Quanto a classificação do arroz beneficiado e polido, o MINISTÉRIO DA AGRICULTURA (1988) considerou cinco classes de acordo com as dimensões dos grãos: longo fino, longo, médio, curto e misturado. 
Para tal classificação, considera-se as dimensões dos grãos de uma amostra de dez gramas dos grãos inteiros beneficiados e polidos de cada tratamento, sendo as classes identificadas da seguinte maneira:

- Longo fino, quando no mínimo $80 \%$ dos grãos medir $6,0 \mathrm{~mm}$ ou mais de comprimento, $1,85 \mathrm{~mm}$ de espessura e cuja relação comprimento/largura seja igual ou superior a $3 \mathrm{~mm}$.

- Longo, quando no mínimo $80 \%$ dos grãos medir $6,0 \mathrm{~mm}$ ou mais de comprimento.

- Médio, quando no mínimo $80 \%$ dos grãos medir de 5,0 a $6,0 \mathrm{~mm}$ de comprimento.

- Curto, quando no mínimo $80 \%$ dos grãos medir menos de 5,0 mm de comprimento.

- Misturado, quando menos de $80 \%$ de uma das classes anteriores apresentar-se constituído por duas ou três das classes distintas

O cultivar IAC 201, lançado pelo Instituto Agronômico de Campinas em 1992; foi o primeiro representante da classe de grão longo fino (agulhinha) de sequeiro disponível no Brasil (BASTOS et al., 1994).

Segundo GUIMARĀES (1989), as variedades cultivadas no sistema de sequeiro no Brasil, descendentes do grupo japônico, apresentava grão da classe longo, com comprimento acima de $6,0 \mathrm{~mm}$, sem especificação para largura e espessura. 
O mesmo autor relata que tipos de grão longo não atendem a preferência do consumo interno, que faz opção pelo "agulhinha". Em decorrência da não preferência do consumidor; o preço do produto é de 20 a $50 \%$ inferior ao agulhinha irrigado, ainda expõem-se aos riscos inerentes ao sistema de cultivo (GUTMARÃES, 1989).

Para tanto, os programas de melhoramento do arroz de sequeiro têm priorizado a qualidade de grão, objetivando a competitividade com variedades produzidas no sistema irrigado. Ainda é relatado pelo autor que as características de dimensões de grão são de alta herdabilidade, portanto, relativamente fácil para serem melhoradas

\subsection{Alguns resultados obtidos pelo emprego de agentes mutagênicos, no melhoramento do arroz}

A utilização de mutagênicos tem sido freqüente no melhoramento de plantas. Em arroz, a FAO/IAEA (1991) relatou 278 variedades melhoradas utilizando esta metodologia, além de 80 variedades obtidas através da recombinação de linhagens mutantes com outros genótipos pelos métodos convencionais.

Kawai (1962), citado por CHANDRARATNA (1964), utilizando raios-beta e raios-gama, conseguiu mutantes de arroz desejáveis a partir da variedade Norin.$^{\circ}$ 8. Com raios-beta foi possível reduzir a altura do colmo em até $13 \%$ e aumentar o número de panículas por plantas em até $29 \%$. Utilizando raios-gama, o autor 
aumentou a produção de grãos em até $10 \%$, e o comprimento da panícula em $6 \%$. Todavia, não foi possível reunir todas essas características num único mutante.

KAWAI (1968), realizando estudos genéticos em cinco linhagens mutantes de porte baixo, selecionadas à partir da variedade Norin n. $^{\circ} 8$, observou que 0 período para o início do florescimento, o número de grãos por panícula e o número de panículas por planta, praticamente não foram alterados. Já o comprimento do colmo, da panícula e o peso de 1.000 grãos diminuíram.

MIAH \& BHATTI (1968) trabalharam com duas variedades de arroz, Kangni-27 e Dokri Basmati. As sementes foram irradiadas com 20, 25, 30, 40, 45 e $50 \mathrm{KR}$ de raios-gama. Os autores isolaram, na geração $\mathrm{M}_{3}, 19$ mutantes de porte baixo, Tendo o mutante S-15 apresentado altura $20 \%$ mais baixa do que o controle. Todavia, todos os mutantes de porte baixo floresceram mais tarde que o controle. Os autores relatam que muitos trabalhos têm reportado que, com o emprego de substâncias mutagênicas, pode-se obter precocidade, colmo de porte menor, resistência às doenças e aumento de produção.

Segundo REE (1968), a partir do tratamento de 2 variedades de arroz com raios- $\mathrm{X}$ e neutrons térmicos, foram obtidas, na geração $\mathrm{M}_{4}, 12$ linhagens mutantes que eram de 4 a 8 dias mais precoces do que as variedades originais.

TANAKA (1968), trabalhando com a variedade de arroz Norin $n .^{\circ}$ 8, estudou seis caracteres: comprimento do colmo, comprimento da panícula, número de panículas por planta, número de grãos por panícula, peso de panículas por planta e 
número de dias até o florescimento. Com exposição crônica de raios-gama, o autor obteve o seguinte resultado na geração $\mathrm{M}_{2}$ : mutantes com colmo de porte baixo ocorreram mais freqüentemente do que os mutantes com porte alto, portanto o tratamento foi eficiente para reduzir o porte do colmo em até $70 \%$ em relação a variedade original. $\mathrm{O}$ tratamento mutagênico não foi eficiente para diminuir o número de dias até o florescimento. A ordem decrescente da freqüência de mutação para os seis caracteres foi: peso de panículas por planta $>$ numero de grãos por panícula $>$ comprimento do colmo $>$ comprimento da panícula $>$ número de panícula por planta $>$ número de dias para o início do florescimento.

ANGLADETTE (1968) afirmou que, com o uso de substâncias mutagênicas, pode-se obter um determinado número de mutantes com menor grau de heterozigose, em comparação com os heterozigotos $F_{2}$ obtidos por hibridação. Os mutantes são heterozigotos para um número reduzido de fatores genéticos. Dessa maneira, espera-se obter linhagens mutantes estáveis a partir do $4 .^{\circ}$ ou $5 .^{\circ}$ ano após o tratamento, contra pelo menos dez anos para o caso de hibridação. $\mathrm{O}$ autor relata que tratamentos mutagênicos no arroz permitem obter plantas de porte baixo, com ciclo mais precoce, e alteração no comprimento e largura do grão, entre outros efeitos.

Li (1957), citado por SIGURBJORNSSON \& MICKE (1969), utilizando raios- $\mathrm{X}$ em arroz, conseguiu mutantes de alta produção e de período de crescimento reduzido.

GOVINDASWAMI et al. (1972), tratando o cultivar "CR 75-93" com 15, 25 e $35 \mathrm{KR}$ de raios-gama, conseguiram isolar, em M2, um largo numero de 
mutantes com caracteres alterados, tais como: redução na altura da planta, aumento do peso de 1.000 grãos e aumento do comprimento do grão. Quanto ao teor de proteína, este não foi alterado pelo tratamento mutagênico.

RUTGER (1977) relata que os programas de melhoramento do arroz nos Estados Unidos têm utilizado a técnica da indução de mutação com sucesso, para induzir baixa estatura e precocidade.

DWIVEDI et al. (1979), trabalhando com duas variedades de arroz, após o tratamento com $10 \mathrm{Krad}$ de raios-gama, isolaram na geração $\mathrm{M}_{4}$ dois mutantes que apresentavam a metade da altura original.

O tempo de florescimento não foi alterado, porém, o comprimento da panícula nas linhagens mutantes foi sensivelmente menor em comparação com o controle, e o número de grãos por panícula foi menor nas linhagens mutantes. Para esses autores, o nanismo está associado com os seguintes caracteres: menor número de perfilhos, redução no comprimento da panícula, tamanho de grãos, comprimento das folhas, densidades de espiguetas e grãos finos. Várias mudanças morfológicas associadas com o nanismo podem ser atribuídas a genes maiores, que condicionam o nanismo.

SARALA \& REDDY (1979) afirmaram que a linhagem mutante de arroz HR-5-3, obtida do tratamento com 0,5\% de EMS (metanossulfonato de etila), possui $38 \%$ mais proteína, quando comparada com a variedade original.

BHIVARE \& DAS (1980) relataram que, com tratamento de 30 Krad de raios-gama, obtiveram um mutante com grãos finos $(6,57 \mathrm{~mm}$ de comprimento, $1,92 \mathrm{~mm}$ de largura e relação comprimento/largura $=3,42$ ) ao passo que a variedade 
original (IR-8) possuía $6,54 \mathrm{~mm}$ de comprimento, $2,37 \mathrm{~mm}$ de largura e relação comprimento/largura $=2,76$. Todavia, em relação à produção de grãos, a linhagem mutante foi pouco inferior à original. Com o emprego de $10 \mathrm{Krad}$, os autores conseguiram grãos mais compridos: 7,23 $\mathrm{mm}$ de comprimento, $2,30 \mathrm{~mm}$ de largura, com relação comprimento/largura $=3,14$. No entanto essa linhagem de grãos mais compridos teve a maturação 17 dias mais tardia que o controle (IR-8). Do tratamento com $20 \mathrm{Krad}$, os autores obtiveram, ainda, mutantes de alta capacidade produtiva, que possuíam panículas maiores, com um grande número de grãos por panícula. Do tratamento de sementes da variedade Patnai-23 com $30 \mathrm{Krad}$, conseguiram isolar um mutante com $106 \mathrm{~cm}$ de altura, quando o controle possuía $156 \mathrm{~cm}$ de altura. Todavia, esse mutante de porte baixo apresentava ciclo longo (160 dias da semeadura a $80 \%$ de maturação de grãos) e as folhas estreitas.

BORAH \& GOSWAMI (1981) trataram sementes do cultivar Pusa-33 (porte anão, $77,14 \mathrm{~cm}$ ) com $0,45 \%$ de EMS a $\mathrm{pH}=9,0$. Na geração $\mathrm{M}_{3}$, obtiveram um mutante semi-anão e de grãos super finos. Esse mutante, denominado de "Sonalee", foi superior ao tipo parental em: altura da planta, comprimento da panícula, número de grãos férteis por panícula, número de grãos férteis por planta, produção por planta, peso de 1.000 grãos, comprimento do grãos e teor de proteína.

MAHADEVAPPA et al. (1981) citaram que o tratamento com etilenimina (EI) a 0, 2 e 0, 4\% de concentração por uma hora e três horas de tratamento, respectivamente, induz precocidade e baixa estatura em arroz. Nesses mutantes de porte baixo, o número de grãos por panícula foi significativamente reduzido. Todavia, a 
redução na produção de grãos devido a redução do número de grãos por panícula pode ser compensada pelo aumento da densidade de plantio.

MIAH et al. (1981) trataram sementes da variedade $\mathbb{R}-8$ com raiosgama e, na geração $\mathrm{M}_{5}$, isolaram linhagens mutantes com alta produção e precocidade (uma delas era 41 dias mais precoce que o controle).

SHARMA \& LAL (1981) observaram que o comprimento e a largura do grão são facilmente afetados pelo tratamento com EMS, e que o tratamento tem efeito bilateral. Com relação a altura da planta, os autores verificaram que, em todos os tratamentos, a média da altura das plantas $\mathbf{M}_{2}$ foi significativamente menor que $o$ controle "Jagannathll". O tratamento com EMS causou variação unidirecional, para plantas baixas. Entretanto, no tratamento de sementes variedade "Rexero R11", a média da altura da planta foi maior que o controle em todas as linhagens obtidas. 


\section{MATERIAL}

As linhagens testadas são resultantes de um trabalho iniciado em 1987, objetivando seleção de plantas mutantes de porte baixo e precocidade, separadamente, da variedade Dourado Precoce, após o tratamento das sementes com o mutagênico químico azida sódica $\left(\mathrm{NaN}_{3}\right)$. Os trabalhos de indução de mutação e seleção das linhagens foram realizados no Departamento de Genética da Escola Superior de Agricultura "Luiz de Queiroz"/USP em colaboração com a Seção de Radiogenética do Centro de Energia Nuclear na Agricultura/USP.

Após quatro ciclos de seleção, foram selecionadas várias linhagens $\mathrm{M}_{5}$ das quais as 14 mais promissoras foram enumeradas como mutantes de 1 a 14 , seguidas dos cultivares Dourado Precoce e IAC 201, respectivamente, para serem testadas em ensaio de caracterização.

O cultivar IAC 201, recomendado para o Estado de São Paulo a partir de 1992, foi incluso neste experimento por apresentar melhor qualidade e tipo de grão em relação aos demais cultivares de sequeiro disponíveis e também devido ao 
interesse de incluir um cultivar atual, uma vez que o Dourado Precoce não é mais recomendado.

Já o cultivar Dourado Precoce foi incluso por ser o cultivar que originou os mutantes. Este apresenta como inconveniente porte alto da planta, o que ocasiona perdas devido ao acamamento na ocasião da maturação.

Portanto, foram utilizadas 14 linhagens mutantes selecionadas e dois cultivares de arroz de sequeiro, totalizando 16 tratamentos.

\section{MÉTODOS}

Com o objetivo de uniformizar o material utilizado na semeadura, as sementes foram previamente abanadas com peneira manual, de maneira a eliminar as sementes mal granadas.

Para obtenção dos dados experimentais, as linhagens e variedades foram dispostas em quatro blocos, no Centro Experimental de Campinas do Instituto Agronômico, de acordo com o delineamento estatístico de blocos casualizados. Dentro de bloco (repetição), cada parcela experimental foi constituída de cinco fileiras paralelas de quatro metros de comprimento espaçadas de $50 \mathrm{~cm}$. Em cada parcela, foram semeadas 1.500 sementes tendo em cada fileira 300 . Todas as observações foram realizadas nas três 
linhas centrais de cada parcela, visando minimizar os possíveis efeitos de bordadura entre os tratamentos. O experimento foi realizado no ano agrícola de 1993/94.

Os tratos culturais foram realizados conforme as recomendações técnicas para o cultivo do arroz de sequeiro no Estado de São Paulo (TISSELLI \& AZZINI, 1990). Nessas condições, os caracteres estudados foram avaliados em cada uma das quatro repetições, e com média do caracter de cada repetição foi realizada a análise estatística.

\subsection{Caracteres avaliados}

\subsubsection{Número de dias até o florescimento e até a maturação}

Para determinação destes caracteres, foi protocolado o dia em que cada parcela apresentou visualmente 50\% das flores emitidas, (AZZINI et al., 1995), e da mesma forma a maturação foi protocolada quando $50 \%$ das panículas apresentavam-se maduras. O número de dias até o florescimento e maturação foram calculados a partir da emergência das plântulas. 


\subsubsection{Número de perfilhos por planta}

Foram efetuadas três amostragens de um metro linear ao acaso em cada parcela, antes do perfilhamento (10 dias após a emergência), e desta contagem foi estabelecido o estande inicial médio para cada repetição.

A avaliação do perfilhamento (estande final) foi realizada contando-se o número de perfilhos pelo mesmo procedimento utilizado para determinar o estande inicial, porém na ocasião da maturação. O número médio de perfilhos de cada repetição foi dividido pela média do número de plantas observadas do estande inicial, para determinação do perfilhamento médio por planta em cada repetição.

\subsubsection{Altura da planta}

A altura da planta foi tomada em centímetros, com o emprego de régua de $1,5 \mathrm{~m}$, com precisão de $1 \mathrm{~cm}$, a qual foi apoiada no solo junto à planta, sendo estimado seu comprimento da base da planta até a extremidade da panícula do colmo mais alto (AZZINI et al., 1995).

Para cada repetição, foram feitas medidas em dez plantas diferentes tomadas ao acaso na ocasião da maturação (SOARES, 1993), e destes dez valores calculou-se a média que passou a representar cada parcela. 


\subsubsection{Número de panículas por $\mathrm{m}^{2}$}

Por ocasião da colheita, foi tomado ao acaso um metro linear em cada parcela, onde todas as panículas foram colhidas e contadas. Os valores finais foram transformados em número de panículas por $\mathrm{m}^{2}$.

\subsubsection{Comprimento das panículas}

O comprimento da panícula foi medido utilizando-se todas as panículas colhidas para avaliação do número de panícula por $\mathrm{m}^{2}$. As medidas foram feitas a pārtir do primeiro nó até a extremidade do último grão (GRIST, 1965; SILVA; 1976; EMBRAPA, 1977). Para avaliação do comprimento das panículas, número de espiguetas granadas por panícula e porcentagem de espiguetas estéreis, foram tomadas em média $108 \pm 23$ panícula por parcela. Esta avaliação foi feita em laboratório utilizando-se régua milimetrada e a média observada entre todas as panículas representou suas respectivas parcelas.

\subsubsection{Número de espiguetas granadas por panícula}

Foram contados os grãos de todas as panículas colhidas em cada parcela para avaliação do comprimento da panícula (108 \pm 23 em média), e da mesma maneira a parcela foi representada pela média do número de grãos entre todas as panículas. 


\subsubsection{Porcentagem de espiguetas estéreis por panícula}

A esterilidade foi avaliada em porcentagem, considerando as mesmas panículas avaliadas na determinação do número de espiguetas granadas por panícula. Para tanto, todas as panículas foram debulhadas e as espiguetas separadas manualmente em dois grupos: granadas e estéreis. Só foram consideradas estéreis as espiguetas totalmente chochas e, com a média percentual de cada parcela, foram feitas as análises estatísticas.

\subsubsection{Peso de 1.000 grãos}

Esta determinação foi realizada através da obtenção de oito amostras de 100 sementes por parcela com umidade de $13 \%$, pesadas em balança de precisão de 0,01 g. Quando o coeficiente de variação das oito amostras não ultrapassou $6 \%$, multiplicou-se o resultado médio do peso das amostras por 10 para obter o peso de 1.000 grãos para cada parcela, conforme as regras para análise de sementes (BRASI, M.A., 1992).

\subsubsection{Produtividade}

A produtividade foi avaliada utilizando-se o total de grãos colhidos por parcela (três fileiras centrais, $6 \mathrm{~m}^{2}$ ), incluindo-se os grãos colhidos em um metro linear, para as avaliações anteriores. As impurezas e espiguetas estéreis foram separadas 
por abanação utilizando-se peneira manual. A pesagem foi realizada com o emprego de uma balança mecânica de capacidade para $10 \mathrm{~kg}$, quando os grãos apresentavam em torno de $13 \%$ de umidade. Após as análises estatísticas, as médias de produção de grãos foram transformadas para produtividade $\mathrm{em} \mathrm{kg} / \mathrm{ha}$.

\subsubsection{Renda}

A avaliação da renda, que corresponde ao total de grãos beneficiados e polidos, foi feita a partir do beneficiamento de uma amostra de 100 gramas da produção total de cada parcela com $13 \%$ de umidade, pesada em balança da precisão de 0,01 g. Para tal operação, utilizou-se uma máquina para beneficiamento de pequenas amostras (Rice Testing Machine, Suzuki). O total de grãos beneficiados e polidos (inteiros e quebrados) foram pesados. Os pesos obtidos foram utilizados para realizar a análise estatística.

\subsubsection{Rendimento}

O rendimento é representado pelo total de grãos inteiros (beneficiados e polidos) da amostra $100 \mathrm{~g}$ em casca. Para esta avaliação os grãos foram separados utilizando-se do trieur da própria máquina utilizada para fazer o beneficiamento. Após separação dos grãos inteiros, os mesmos foram pesados utilizandose a mesma balança em que foi feita a pesagem da renda. 


\subsubsection{Classificação quanto ao tipo de grão}

Utilizou-se dez gramas de grãos inteiros beneficiados e polidos, retirados de forma aleatória de cada tratamento. Em seguida, os grãos foram medidos e separados em cinco classes: longo fino, longo, médio, curto e misturado, utilizando-se um medidor de grão, com precisão de 0,01mm (Grain Measure, Japão). Após separação, as classes foram pesadas individualmente e os valores transformados em porcentagem. Foram classificados como: longo fino - os mutantes que continham no mínimo $80 \%$ dos grãos medindo no mínimo $6,0 \mathrm{~mm}$ de comprimento e no máximo $1,85 \mathrm{~mm}$ de espessura; longo - no mínimo $80 \%$ dos medindo mínimo $6,0 \mathrm{~mm}$; médio - no mínimo $80 \%$ dos grãos medindo de 5 a 6,0mm de comprimento; curto -no mínimo $80 \%$ dos grãos medindo menos de 5,0 mm de comprimento; misturados - menos de $80 \%$ dos grão constituídos por duas ou três classes distintas.

\subsubsection{Comprimento, largura e espessura do grão}

Comprimento, largura e espessura do grão foram avaliados através da amostragem em 25 grãos beneficiados e polidos de cada parcela. A medição foi feita utilizando-se o mesmo medidor de grãos (Grain Measure, Japão) de precisão de $0,01 \mathrm{~mm}$. Cada parcela foi representada pela média observada nos 25 grãos. 


\subsubsection{Relação comprimento/largura do grão}

A relação comprimento/largura do grão foi determinada utilizando-se os valores de comprimento e largura obtidos para avaliação destes caracteres individuais. Para tanto, o comprimento foi dividido pela largura e a média dos valores observados passou a representar a parcela.

\subsection{Análise Estatística}

As análises estatísticas foram realizadas, aplicando-se o teste de Tukey à análise da variância. A significância dos Quadrados Médios (QM) e o coeficiente de variação (CV) foram obtidos utilizando-se o programa de análise estatística (SANEST), e as médias foram comparadas pelo teste de Tukey a 1 e $5 \%$ de probabilidade. Segue o esquema da análise da variância utilizada.

\begin{tabular}{lclll}
\hline \multicolumn{1}{c}{ C.V. } & G.L. & S.Q. & Q.M. & F \\
\hline Tratamentos & 15 & SQTrat. & QMTrat. & \\
Blocos & 3 & SQBlocos & QMBlocos & \\
Resíduo & 45 & SQRes. & QMRes. & \\
\hline Total & 63 & SQTotal & \\
\hline
\end{tabular}


sendo: $\quad \phi(t)=\frac{1}{I-1} \sum_{i=1}^{I} t_{i}^{2}$

SQTotal $=\sum_{i=1}^{I} \sum_{J=1}^{J}\left(y_{i}-\bar{y} . .\right)^{2}$, associada a (IJ-1) graus de liberdade, então tem-se que:

$$
\text { SQTotal }=\sum_{i=1}^{I} \sum_{j=1}^{J} \frac{2}{y_{\nu}}-\frac{y_{. .}^{2}}{I J}
$$

$S Q T r a t=J \sum_{i=1}^{I}\left(\bar{y}_{. j}-\bar{y}_{. .}\right)^{2}$, associada a (I-1) graus de liberdade, então, tem-se que:

$$
\text { SQTrat }=\frac{1}{J} \sum_{i=1}^{I} \cdot{ }^{2}-\frac{y_{i .}^{2}}{I J}
$$

$S Q B l o c o s=I \sum_{j=1}^{J}\left(\bar{y}_{\cdot j}-\bar{y}_{. .}\right)^{2}$, associada a (J-1) graus de liberdade, tem-se, então, que:

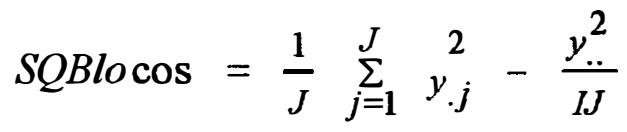




\section{RESULTADOS E DISCUSSÃO}

5.1. Quadrados médios, teste F, coeficiente de variação (CV\%), médias, variância, coeficiente de variação genética e herdabilidade

Os quadrados médios obtidos nas análises de variâncias dos caracteres, mostrados na Tabela 1, permitem constatar que apenas o número de perfilho por planta, comprimento do grão e renda não apresentaram diferenças significativas entre os tratamentos, sendo os demais caracteres significativos conforme o nível indicado.

Ainda na Tabela 1, são apresentados os coeficientes de variação experimental (CV). Com exceção ao caráter porcentagem de espiguetas estéreis por panícula que teve CV alto (26,69\%), os valores obtidos; foram de baixa magnitude, o que confirmam excelente precisão experimental de acordo com GOMES (1984). O valor alto observado o para caráter número de grãos estéreis por panícula, indica que este caráter é mais influenciável pelo ambiente. Com relação ao coeficiente de variação genética (CVg), 
(Tabela 1) apenas para o caracter porcentagem de espiguetas estéreis por panícula teve valor alto $(43,71 \%)$, os demais caracteres tiveram valores baixo inferior a $15 \%$.

Foram calculadas também as estimativas da herdabilidade no sentido amplo $\left(\mathrm{h}_{\mathrm{a}}^{2}\right.$ ), sendo verificado que, com exceção dos caracteres renda e comprimento de grãos que tiveram $h^{2}=0,54$ e 0,13 , respectivamente, os demais caracteres apresentaram $h^{2}$ alta, igual ou superior a 79\%, indicando que há grande variação genética entre os tratamentos. Para todos os caracteres houve predominância da variância genética sobre a variância ambiental, pois os valores de $\mathrm{CVg}$ são superiores ao $\mathrm{CV}$, o que indica valores de índice $\underline{\mathrm{b}} \quad \frac{\mathrm{CVg}}{\mathrm{CV}}$ superiores a 1 .

\subsection{Número de dias até o florescimento e até a maturação}

Não houve diferença significativa entre os tratamentos com relação ao numero de dias até o florescimento e número de dias até a maturação. Os mutantes, assim como as testemunhas, tiveram de 68 a 73 dias da emergência ao florescimento e de 90 a 96 dias até a maturação, o que os classifica como precoces (EMBRAPA 1977; SAINI \& KUMAR,1978). 
Tabela 1. Resumo da analise de variância, coeficiente de variação (CV\%), médias, variância, coeficiente de variação genética (CVg\%) e herdabilidade $\left(\mathrm{h}_{\mathrm{a}}{ }_{\mathrm{a}}\right)$ para os caracteres avaliados.

\begin{tabular}{|c|c|c|c|c|c|c|c|c|}
\hline Caracteres & Fontes de variaçōes & $\mathbf{G L}$ & $\mathbf{Q M}$ & Média & CV(\%) & $\hat{\tilde{\sigma}}_{g}^{2}$ & $\mathrm{CVg}(\%)$ & $\mathbf{h}_{\mathrm{a}}^{2}$ \\
\hline Número de perfilhos/planta & $\begin{array}{c}\text { Tratamento } \\
\text { Resíduo }\end{array}$ & $\begin{array}{l}15 \\
45\end{array}$ & $\begin{array}{l}0,5374 \mathrm{~ns} \\
0,0958\end{array}$ & 2,25 & 13,77 & 0,1104 & 14,78 & 0,82 \\
\hline Altura das plantas & $\begin{array}{c}\text { Tratamento } \\
\text { Resíduo }\end{array}$ & $\begin{array}{l}15 \\
45\end{array}$ & $\begin{array}{c}994,1555 * * \\
27,5599\end{array}$ & 122,08 & 4,30 & 241,6489 & 12,73 & 0,97 \\
\hline Número de panículas $/ \mathrm{m}^{2}$ & $\begin{array}{c}\text { Tratamento } \\
\text { Resíduo }\end{array}$ & $\begin{array}{l}15 \\
45\end{array}$ & $\begin{array}{c}1.148,0291 \\
223,2875\end{array} * *$ & 109,66 & 13,74 & 231,1894 & 13,86 & 0,80 \\
\hline Comprimento das panículas & $\begin{array}{c}\text { Tratamento } \\
\text { Resíduo }\end{array}$ & $\begin{array}{l}15 \\
45\end{array}$ & $\begin{array}{c}10,9085 \\
1,1217\end{array}$ & 21,15 & 5,00 & 2,4467 & 7,40 & 0,90 \\
\hline Número de espiguetas/panículas & $\begin{array}{c}\text { Tratamento } \\
\text { Resíduo }\end{array}$ & $\begin{array}{l}15 \\
45\end{array}$ & $\begin{array}{c}2.621,9468 * * \\
121,8040\end{array}$ & 94,28 & 11,71 & 625,0357 & 26,50 & 0,95 \\
\hline Porcentagem de espiguetas estéreis/panícula & $\begin{array}{c}\text { Tratamento } \\
\text { Resíduo }\end{array}$ & $\begin{array}{l}15 \\
45\end{array}$ & $\begin{array}{c}59,5931 * * \\
5,0807\end{array}$ & 8,44 & 26,69 & 13,6281 & 43,71 & 0,91 \\
\hline Peso de 1.000 grãos & $\begin{array}{c}\text { Tratamento } \\
\text { Resíduo }\end{array}$ & $\begin{array}{l}15 \\
45\end{array}$ & $\begin{array}{c}53,1660 * * \\
0,3087\end{array}$ & 32,61 & 1,70 & 13,2143 & 11,15 & 0,99 \\
\hline Produtividade & $\begin{array}{c}\text { Tratamento } \\
\text { Resíduo }\end{array}$ & $\begin{array}{l}15 \\
45\end{array}$ & $\begin{array}{l}1,2036 * * \\
0,1270\end{array}$ & 3,537 & 10,07 & 0,2691 & 14,67 & 0,89 \\
\hline Renda & $\begin{array}{c}\text { Tratamento } \\
\text { Resíduo }\end{array}$ & $\begin{array}{l}15 \\
45\end{array}$ & $\begin{array}{l}4,0748 \mathrm{~ns} \\
1,8791\end{array}$ & 74,21 & 1,85 & 0,5489 & 1,00 & 0,54 \\
\hline Rendimento & $\begin{array}{c}\text { Tratamento } \\
\text { Resíduo }\end{array}$ & $\begin{array}{l}15 \\
45\end{array}$ & $\begin{array}{c}19,7469 * \\
4,2231\end{array}$ & 68,02 & 3,02 & 3,8809 & 2,90 & 0,79 \\
\hline Comprimento do grão & $\begin{array}{c}\text { Tratamento } \\
\text { Resíduo }\end{array}$ & $\begin{array}{l}15 \\
45\end{array}$ & $\begin{array}{l}0,4612 \text { ns } \\
0,4015\end{array}$ & 7,02 & 9,03 & 0,0149 & 1,74 & 0,13 \\
\hline Largura do grão & $\begin{array}{c}\text { Tratamento } \\
\text { Residuo }\end{array}$ & $\begin{array}{l}15 \\
45\end{array}$ & $\begin{array}{l}0,0854 * * \\
0,0009\end{array}$ & 2,45 & 1,24 & 0,0211 & 5,93 & 0,99 \\
\hline Espessura do grão & $\begin{array}{c}\text { Tratamento } \\
\text { Resíduo }\end{array}$ & $\begin{array}{l}15 \\
45\end{array}$ & $\begin{array}{l}0,0417 * * \\
0,0009\end{array}$ & 1,93 & 1,57 & 0,0102 & 5,23 & 0,98 \\
\hline Relação comprimento/largura & $\begin{array}{c}\text { Tratamento } \\
\text { Resíduo }\end{array}$ & $\begin{array}{l}15 \\
45 \\
\end{array}$ & $\begin{array}{l}0,1598^{* *} \\
0,0016\end{array}$ & 2,90 & 1,37 & 0,0395 & 6,25 & 0,99 \\
\hline
\end{tabular}

ns = não significativo; * = significativo ao nível de $5 \%$ de probabilidade; $* *$ = significativo ao nível de $1 \%$ de probabilidade. 


\subsection{Número de perfilhos por planta}

Os mutantes sete e oito apresentaram as maiores médias de número de perfilhos por planta, sendo diferentes estatisticamente ao nível de $5 \%$ de probabilidade em relação ao cultivar original Dourado Precoce (Tabela 2).

Porém, como afirmaram GERMEK \& BANZATTO (1972) e. SOUZA et al. (1972), este caráter só representa causa importante no aumento da produtividade se não houver diminuição no tamanho da panícula e nem no número de grãos por panícula. Isto é mostrado claramente nas Tabelas 4,5 e 8 , nas quais a redução no tamanho da panícula e no número de grão por panícula foram as causas principais para que o mutante oito apresentasse média de produtividade inferior a Dourado Precoce, apesar deste mutante ter apresentado média superior quanto ao número de perfilhos por planta. Nenhum mutante apresentou média de número de perfilos por planta inferior a Dourado Precoce.

Tabela 2. Médias ordenadas do número de perfilhos por planta

\begin{tabular}{llll}
\hline \multicolumn{1}{c}{ Linhagens/cultivares } & Médias & $\mathbf{5 \%}$ & $\mathbf{1 \%}$ \\
\hline Mutante 7 & 2,85 & $\mathrm{a}$ & $\mathrm{A}$ \\
Mutante 8 & 2,81 & $\mathrm{a}$ & $\mathrm{A}$ \\
Mutante 5 & 2,75 & $\mathrm{ab}$ & $\mathrm{AB}$ \\
Mutante 10 & 2,56 & $\mathrm{abc}$ & $\mathrm{ABC}$ \\
Mutante 4 & 2,53 & $\mathrm{abc}$ & $\mathrm{ABC}$ \\
Mutante 9 & 2,46 & $\mathrm{abc}$ & $\mathrm{ABC}$ \\
IAC 201 & 2,25 & $\mathrm{abc}$ & $\mathrm{ABC}$ \\
Mutante 13 & 2,16 & $\mathrm{abc}$ & $\mathrm{ABC}$ \\
Mutante 1 & 2,16 & $\mathrm{abc}$ & $\mathrm{ABC}$ \\
Mutante 2 & 2,10 & $\mathrm{abc}$ & $\mathrm{ABC}$ \\
Dourado Precoce & 1,99 & $\mathrm{bc}$ & $\mathrm{ABC}$ \\
Mutante 3 & 1,98 & $\mathrm{bc}$ & $\mathrm{ABC}$ \\
Mutante 14 & 1,87 & $\mathrm{c}$ & $\mathrm{BC}$ \\
Mutante 12 & 1,86 & $\mathrm{c}$ & $\mathrm{BC}$ \\
Mutante 11 & 1,85 & $\mathrm{c}$ & $\mathrm{BC}$ \\
Mutante 6 & 1,77 & $\mathrm{c}$ & $\mathrm{C}$ \\
\hline
\end{tabular}

Médias seguidas por letras distintas diferem entre si ao nivel de significância indicado. 


\subsection{Altura da planta}

Os mutantes oito, quatro, dez, cinco, nove e sete tiveram as menores médias de altura, significativas ao nível de $1 \%$ de probabilidade da cultivar original Dourado Precoce (Tabela 3). Deve-se ainda ressaltar que os mutantes quatro, dez, cinco, nove e sete não diferem estatisticamente do cultivar IAC 201, que apresenta porte médio nas condições de cultivo dos agricultores. O mutante sete, mesmo apresentando redução na altura da planta, manteve a mesma produtividade quando comparado com as testemunhas Dourado Precoce e IAC 201 (Tabela 9).

Nenhum mutante mostrou, significativamente, altura média superior a variedade Dourado Precoce. Foi observado início de acamamento no campo nos mutantes 14 e 12 que apresentaram maiores médias de alturas, 137,89 e 137,40 cm, respectivamente, evidenciando que maiores alturas das plantas tornariam mais propensas ao acamamento, como relatam JENNINGS et al. (1979) e GERMEK \& BANZATTO (1972).

\subsection{Número de panículas por $\mathrm{m}^{2}$}

$\mathrm{Na}$ Tabela 4, pode-se observar que não houve diferença significativas entre os mutante e o Dourado Precoce. Embora o mutante cinco tenha apresentado média superior ao mutante 13 a $1 \%$ de probabilidade, e o mutante dez 
superior ao mutante três a $5 \%$ de probabilidade, os mesmos não se apresentaram estatisticamente diferentes quanto à produtividade (Tabela 9).

Estes resultados indicam que a redução no tamanho da panícula e o aumento no percentual de espiguetas estéreis, observados no mutante oito (Tabela 5 e 7), foram as principais causas para a redução na produtividade do mesmo.

Tabela 3. Médias ordenadas da altura das plantas (cm).

\begin{tabular}{llll}
\hline \multicolumn{1}{c}{ Linhagens/cultivares } & Médias & $\mathbf{5 \%}$ & $\mathbf{1 \%}$ \\
\hline Mutante 14 & 137,89 & a & A \\
Mutante 12 & 137,40 & a & A \\
Mutante 11 & 137,40 & a & A \\
Mutante 6 & 135,90 & a & A \\
Dourado Precoce & 135,84 & a & A \\
Mutante 3 & 133,74 & a & AB \\
Mutante 2 & 132,34 & ab & AB \\
Mutante 13 & 128,25 & ab & AB \\
Mutante 1 & 124,64 & abc & ABC \\
IAC 201 & 119,94 & bcd & BCD \\
Mutante 7 & 112,55 & cd & CD \\
Mutante 9 & 112,00 & cd & CD \\
Mutante 5 & 107,70 & d & D \\
Mutante 10 & 107,60 & d & D \\
Mutante 4 & 106,60 & d & D \\
Mutante 8 & 83,50 & e & E \\
\hline
\end{tabular}


Tabela 4. Médias ordenadas do número de panículas por $\mathrm{m}^{2}$

\begin{tabular}{|c|c|c|c|}
\hline Linhagens/cultivares & Média & $5 \%$ & $1 \%$ \\
\hline Mutante 5 & 267,50 & $\mathbf{a}$ & A \\
\hline Mutante 10 & 260,50 & $\mathbf{a}$ & $\mathrm{AB}$ \\
\hline Mutante 4 & 256,00 & $a b$ & $\mathrm{AB}$ \\
\hline Mutante 8 & 252,00 & abc. & $\mathrm{ABC}$ \\
\hline Mutante 7 & 250,50 & abc & $\mathrm{ABC}$ \\
\hline Mutante 9 & 246,50 & $a b c$ & $\mathrm{ABC}$ \\
\hline Mutante 12 & 233,50 & abcd & $\mathrm{ABC}$ \\
\hline Mutante 14 & 208,00 & abcd & $\mathrm{ABC}$ \\
\hline Mutante 6 & 197,50 & abcd & $\mathrm{ABC}$ \\
\hline Mutante 11 & 197,00 & abcd & $\mathrm{ABC}$ \\
\hline Mutante 2 & 195,50 & abcd & $\mathrm{ABC}$ \\
\hline Dourado Precoce & 195,50 & abcd & $\mathrm{ABC}$ \\
\hline IAC 201 & 194,00 & abcd & $\mathrm{ABC}$ \\
\hline Mutante 1 & 183,50 & abcd & $\mathrm{ABC}$ \\
\hline Mutante 3 & 176,00 & cd & BC \\
\hline Mutante 13 & 165,50 & d & C \\
\hline
\end{tabular}




\subsection{Comprimento das panículas}

A Tabela 5 permite constatar que as médias do comprimento da panícula foram etatisticamente inferiores nos mutantes oito, nove e dez a $5 \%$ de probabilidade, em comparação com a variedade original Dourado Precoce. Estes mesmos mutantes apresentaram médias inferiores no número de grão por panícula (Tabela 6), evidenciando que a redução no tamanho da panícula causou a diminuição do número de grão por panícula.

\subsection{Número de grãos por panícula}

Os mutantes um, cinco, sete, oito, nove e dez tiveram médias inferiores, ao nível de $1 \%$ de probabilidade, e os mutantes quatro e sete inferiores ao nível de 5\% de probabilidade em relação ao Dourado Precoce (Tabela 6). Em nenhum mutante foi observado aumento do número de grãos por panícula.

A redução ao nível de $1 \%$ de probabilidade no número de espiguetas férteis por panícula e comprimento da panícula, e o aumento ao nível da mesma probabilidade no número de espiguetas estéreis por panícula, observado no mutante oito (Tabelas 6, 5 e 7), foram decisivos na redução da média de produtividade do mesmo, uma vez que este apresentou-se como superior nas médias de número de perfilho por planta (Tabela 2) e número de panícula por $\mathrm{m}^{2}$ (Tabela 4). 
Tabela 5. Médias ordenadas do comprimento das panículas (em $\mathrm{cm}$ do primeiro nó até a extremidade da ultima espigueta).

\begin{tabular}{|c|c|c|c|}
\hline Linhagens/cultivares & Médias & $5 \%$ & $1 \%$ \\
\hline IAC 201 & 23,11 & $\mathbf{a}$ & A \\
\hline Dourado Precoce & 23,00 & $\mathbf{a}$ & A \\
\hline Mutante 2 & 22,57 & $a b$ & A \\
\hline Mutante 3 & 22,48 & $a b$ & A \\
\hline Mutante 14 & 22,18 & $a b$ & A \\
\hline Mutante 6 & 21,87 & $a b$ & $A B$ \\
\hline Mutante 11 & 21,83 & $a b$ & $\mathrm{AB}$ \\
\hline Mutante 12 & 21,80 & $a b$ & $\mathrm{AB}$ \\
\hline Mutante 7 & 21,43 & abc & $\mathrm{AB}$ \\
\hline Mutante 4 & 20,71 & abc & $A B$ \\
\hline Mutante 13 & 20,66 & abc & $A B$ \\
\hline Mutante 5 & 20,57 & $a b c$ & $\mathrm{AB}$ \\
\hline Mutante 1 & 20,50 & abc & $\mathrm{AB}$ \\
\hline Mutante 9 & 20,13 & bc & $\mathrm{AB}$ \\
\hline Mutante 10 & 18,76 & $\mathrm{~cd}$ & $\mathrm{BC}$ \\
\hline Mutante 8 & 16,75 & d & $\mathrm{C}$ \\
\hline
\end{tabular}


Tabela 6. Médias ordenadas do número de grãos por panícula.

\begin{tabular}{|c|c|c|c|}
\hline Linhagens/cultivares & Média & $5 \%$ & $1 \%$ \\
\hline IAC 201 & 169,53 & $\mathbf{a}$ & A \\
\hline Dourado Precoce & 114,84 & b & B \\
\hline Mutante 11 & 102,58 & bc & BC \\
\hline Mutante 6 & 102,18 & bc & BC \\
\hline Mutante 14 & 102,12 & bc & $\mathrm{BC}$ \\
\hline Mutante 3 & 101,16 & bc & BCD \\
\hline Mutante 12 & 100,39 & bc & BCD \\
\hline Mutante 2 & 98,41 & bc & BCD \\
\hline Mutante 13 & 89,20 & bcd & BCD \\
\hline Mutante 4 & 84,74 & cd & BCD \\
\hline Mutante 7 & 84,35 & cd & BCD \\
\hline Mutante 1 & 80,84 & cd & $\mathrm{CDE}$ \\
\hline Mutante 5 & 80,73 & cd & $\mathrm{CDE}$ \\
\hline Mutante 9 & 79,04 & cd & $\mathrm{CDE}$ \\
\hline Mutante 10 & 68,42 & de & DE \\
\hline Mutante 8 & 49,84 & e & E \\
\hline
\end{tabular}




\subsection{Porcentagem de espiguetas estéreis por panicula}

Na Tabela 7, observa-se que apenas o mutante oito teve média do percentual de espiguetas estéreis por panícula superior ao Dourado Precoce original. Médias inferiores ao cultivar original foram observadas nos mutantes nove e dez (Tabela 7); nestes a redução foi decorrente da diminuição no tamanho da panícula (Tabela 5) e não devido à diminuição do percentual de espiguetas estéreis por panícula.

\subsection{Peso de 1.000 grãos}

$\mathrm{Na}$ Tabela 8 , observa-se que os mutantes um, três e treze tiveram médias do peso de 1000 grãos superiores ao Dourado Precoce original a 5\% de probabilidade. Já os mutantes quatro e sete foram superior a $5 \%$ de probabilidade, e os mutantes cinco, nove e o cultivar IAC 201 tiveram peso de 1.000 grãos inferior ao Dourado Precoce a $1 \%$ de probabilidade

Os resultados mostram eficiência do tratamento com o mutagênico químico azida sódica, para alterar bidirecionalmente o peso de 1.000 grãos, como relatado por BORAH \& GOSWAMI (1981).

\subsection{Produtividade}

Apenas o mutante oito apresentou média de produtividade inferior estatisticamente em relação aos controles (Tabela 9). 
A redução na altura da planta, de alta no Dourado Precoce para média nos mutantes quatro, cinco, sete, nove e dez, observadas na Tabela 3, não causou redução na produtividade. Deve-se ressaltar que tal redução pode permitir a diminuição de sombriamente e conseqüentemente maximizar a absorção de energia solar, o que possibilita redução no espaçamento entre fileiras e, em conseqüência, aumento na produtividade dos mesmos por determinada área.

Tabela 7. Médias ordenadas da porcentagem de espiguetas estéreis por panícula.

\begin{tabular}{lccc}
\hline Linhagens/cultivares & Médias & 5\% & \multicolumn{1}{c}{ 1\% } \\
\hline Mutante 8 & 20,05 & a & A \\
Mutante 3 & 11,90 & b & B \\
Mutante 13 & 11,61 & bc & B \\
Mutante 1 & 11,31 & bc & BC \\
Mutante 2 & 9,70 & bcd & BCD \\
Mutante 6 & 7,96 & bcd & BCD \\
Mutante 4 & 7,47 & bcd & BCD \\
Mutante 14 & 7,21 & bcd & BCD \\
Dourado Precoce & 6,70 & bcd & BCD \\
Mutante 11 & 6,59 & bcd & BCD \\
Mutante 10 & 6,58 & bcd & BCD \\
IAC 201 & 6,58 & bcd & BCD \\
Mutante 5 & 6,17 & bcd & BCD \\
Mutante 12 & 6,03 & cd & BCD \\
Mutante 9 & 4,69 & d & CD \\
Mutante 7 & 4,49 & d & D \\
\hline
\end{tabular}


Tabela 8. Médias ordenadas do peso de 1.000 grãos.

\begin{tabular}{|c|c|c|c|}
\hline Linhagens/cultivares & Médias & $5 \%$ & $1 \%$ \\
\hline Mutante 3 & 37,52 & $\mathbf{a}$ & A \\
\hline Mutante 13 & 37,28 & a & A \\
\hline Mutante 1 & 37,23 & $\mathbf{a}$ & A \\
\hline Mutante 2 & 36,86 & $a b$ & A \\
\hline Mutante 11 & 36,32 & $a b$ & A \\
\hline Mutante 14 & 34,87 & $a b c$ & $\mathrm{AB}$ \\
\hline Dourado Precoce & 34,36 & bc & $\mathrm{ABC}$ \\
\hline Mutante 12 & 32,84 & $\mathrm{~cd}$ & BCD \\
\hline Mutante 6 & 32,82 & $\mathrm{~cd}$ & BCD \\
\hline Mutante 4 & 31,16 & de & CD \\
\hline Mutante 7 & 31,16 & de & CD \\
\hline Mutante 10 & 30,68 & de & D \\
\hline Mutante 5 & 30,53 & de & D \\
\hline Mutante 9 & 30,00 & de & D \\
\hline Mutante 8 & 29,93 & e & D \\
\hline IAC 201 & 24,21 & $\mathrm{f}$ & $\mathbf{E}$ \\
\hline
\end{tabular}


Tabela 9. Médias ordenadas da produtividade de grãos $(\mathrm{kg} / \mathrm{ha})$.

\begin{tabular}{|c|c|c|c|}
\hline Linhagens/cultivares & Médias & $5 \%$ & $1 \%$ \\
\hline Mutante 11 & 6.862 & a & A \\
\hline Mutante 7 & 6.712 & $a b$ & A \\
\hline Mutante 12 & 6.553 & $a b$ & A \\
\hline Mutante 3 & 6.433 & $a b$ & A \\
\hline Mutante 14 & 6.350 & $a b$ & A \\
\hline Dourado Precoce & 6.278 & $a b$ & A \\
\hline IAC 201 & 6.217 & $a b$ & A \\
\hline Mutante 6 & 6.075 & $a b$ & A \\
\hline Mutante 5 & 5.978 & $a b$ & A \\
\hline Mutante 2 & 5.953 & $a b$ & A \\
\hline Mutante 9 & 5.908 & $a b$ & A \\
\hline Mutante 4 & 5.703 & $a b$ & A \\
\hline Mutante 1 & 5.587 & $a b$ & A \\
\hline Mutante 10 & 5.545 & $a b$ & $\mathbf{A}$ \\
\hline Mutante 13 & 5.275 & b & A \\
\hline Mutante 8 & 2.883 & c & B \\
\hline
\end{tabular}




\subsection{Renda}

Nenhum mutante apresentou diferença significativa na renda de grãos beneficiados e polidos, em relação ao Dourado Precoce e IAC 201 (Tabela 10) Este resultado permite afirmar que as diferenças observadas entre as médias do caráter peso de 1.000 grãos nos mutantes $1,3,4,7,8,9,10$ e 12 (Tabela 8), na largura dos grãos nos mutantes 2 e 8 (Tabela 11) e na espessura dos grãos nos mutantes $2,4,5,7,9$ e 10 (Tabela 14) não foram devida à alteração na relação de peso pálea/endosperma da cariopse, mas sim devido a compactação de ambos.

\subsection{Rendimento}

Os resultados da Tabela 12 mostram que não houve diferenças significativas nos mutantes em relação ao Dourado Precoce, porém o mutante cinco, que apresentou maior média de rendimento, difere a $1 \%$ de probabilidade do IAC 201, que apresentou a menor média do caráter, sugerindo que grão do tipo longo fino tendem a apresentar menor rendimento de engenho.

\subsection{Classificação quanto ao tipo de grão}

Todas as linhagens foram classificados como longo, assim como o controle Dourado Precoce. As alterações observadas nas dimensões de grão não foram suficientes para que tivessem classificação diferente do cultivar original. $\mathrm{O}$ cultivar IAC 201 teve classificação como longo fino. 
Tabela 10. Médias ordenadas da renda, avaliada a partir de 100 gramas de grão em casca (valor em gramas dos grãos inteiros e quebrados beneficiado).

\begin{tabular}{|c|c|c|c|}
\hline Linhagens/cultivares & Médias & $5 \%$ & $1 \%$ \\
\hline Mutante 2 & 75,64 & a & $\mathbf{A}$ \\
\hline Mutante 14 & 75,63 & $\mathbf{a}$ & $\mathbf{A}$ \\
\hline Mutante 6 & 75,45 & $\mathbf{a}$ & A \\
\hline Mutante 13 & 75,28 & $\mathbf{a}$ & A \\
\hline Mutante 1 & 74,73 & a & A \\
\hline Mutante 3 & 74,68 & $\mathbf{a}$ & A \\
\hline Mutante 12 & 74,54 & $\mathbf{a}$ & A \\
\hline Dourado Precoce & 74,31 & a & $\mathbf{A}$ \\
\hline Mutante 11 & 74,29 & a & $\mathbf{A}$ \\
\hline Mutante 5 & 74,02 & $\mathbf{a}$ & A \\
\hline Mutante 7 & 73,62 & a & $\mathbf{A}$ \\
\hline Mutante 9 & 73,38 & a & A \\
\hline Mutante 4 & 73,18 & a & A \\
\hline Mutante 10 & 73,02 & a & $\mathrm{A}$ \\
\hline IAC 201 & 72,94 & a & A \\
\hline Mutante 8 & 72,56 & $\mathbf{a}$ & A \\
\hline
\end{tabular}

Médias seguidas por letras distintas diferem entre si ao nivel de significância indicado. 
Tabela 11. Médias ordenadas do rendimento, avaliado a partir de 100 grãos em cascas (valor em gramas de grãos inteiros após o beneficiamento).

\begin{tabular}{|c|c|c|c|}
\hline Linhagens/cultivares & Médias & $5 \%$ & $1 \%$ \\
\hline Mutante 5 & 71,33 & a & A \\
\hline Mutante 7 & 70,80 & $a b$ & $A B$ \\
\hline Mutante 10 & 70,65 & abe & $\mathrm{AB}$ \\
\hline Mutante 4 & 70,30 & abcd & $\mathrm{AB}$ \\
\hline Mutante 6 & 70,01 & abcde & $\mathrm{AB}$ \\
\hline Mutante 9 & 69,98 & abcde & $\mathrm{AB}$ \\
\hline Mutante 12 & 68,38 & abcde & $\mathrm{AB}$ \\
\hline Mutante 14 & 68,02 & abcde & $\mathrm{AB}$ \\
\hline Mutante 1 & 67,64 & abcde & $\mathrm{AB}$ \\
\hline Dourado Precoce & 67,17 & abcde & $\mathrm{AB}$ \\
\hline Mutante 13 & 66,23 & abcde & $\mathrm{AB}$ \\
\hline Mutante 3 & 66,10 & abcdc & $\mathrm{AB}$ \\
\hline Mutante 2 & 65,75 & bcde & $\mathrm{AB}$ \\
\hline Mutante 11 & 65,53 & cde & $\mathrm{AB}$ \\
\hline Mutante 8 & 65,35 & de & $\mathrm{AB}$ \\
\hline IAC 201 & 65,06 & e & B \\
\hline
\end{tabular}

Médias seguidas por letras distintas diferem entre si ao nível de significância indicado. 
Tabela 12. Médias ordenadas da largura dos grãos beneficiados e polidos (mm).

\begin{tabular}{|c|c|c|c|}
\hline Linhagens/cultivares & Médias & $5 \%$ & $1 \%$ \\
\hline Mutante 2 & 2,57 & $\mathbf{a}$ & A \\
\hline Mutante 3 & 2,56 & $a b$ & $\mathrm{AB}$ \\
\hline Mutante 13 & 2,55 & $a b c$ & $\mathrm{AB}$ \\
\hline Mutante 11 & 2,53 & abcd & $\mathrm{ABC}$ \\
\hline Mutante 1 & 2,53 & abcd & $\mathrm{ABC}$ \\
\hline Mutante 14 & 2,52 & abcd & $\mathrm{ABC}$ \\
\hline Mutante 5 & 2,58 & abcde & $A B C D$ \\
\hline Mutante 7 & 2,49 & bcde & $\mathrm{ABCD}$ \\
\hline Mutante 10 & 2,48 & bcde & $\mathrm{ABCD}$ \\
\hline Dourado Precoce & 2,48 & bcde & $\mathrm{ABCD}$ \\
\hline Mutante 4 & 2,48 & cde & BCD \\
\hline Mutante 9 & 2,46 & de & CD \\
\hline Mutante 12 & 2,43 & e & D \\
\hline Mutante 6 & 2,42 & e & D \\
\hline Mutante 8 & 2,28 & f & $\mathrm{E}$ \\
\hline IAC 201 & 1,97 & $\mathrm{~g}$ & $\mathbf{F}$ \\
\hline
\end{tabular}




\subsection{Comprimento, largura e espessura dos grãos beneficiados polidos}

Pode ser observado, na Tabela 13 , que não houve diferença significativa entre os mutantes em relação às testemunhas Dourado Precoce original e IAC 201 quanto ao comprimento do grão. Já quanto à largura, o mutante dois, apresentou média superior ao Dourado Precoce a 5\% de probabilidade e o mutante oito média inferior a $1 \%$ de probabilidade (Tabela 11 ). Com relação à espessura do grão, o mutante dois apresentou média superior a $5 \%$ de probabilidade, o mutante cinco apresentou média inferior ao mesmo nível de probabilidade, e os mutantes sete, dez, nove e quatro, apresentaram médias inferiores ao cultivar original a $1 \%$ de probabilidade (Tabela 14). Estes resultados mostram que, para o cultivar Dourado Precoce, o tratamento com azida sódica possibilita a indução de mutação tanto para o aumento como a diminuição das dimensões dos grãos quanto a largura e espessura.

\subsection{Relação comprimento/largura dos grãos beneficiados e polidos}

Nenhum mutante teve grão com dimensões que pudesse ser classificado como longo fino, igual à variedade testemunha IAC 201. Os mutantes um e oito apresentaram relação comprimento/largura de 3,00 e 3,04, respectivamente (Tabela 15), porém, apresentaram espessuras superiores a $1,85 \mathrm{~mm}$ (Tabela 14), que é o valor máximo para tal classificação. 
Portanto os mutantes foram classificados como longo, assim como o Dourado Precoce original e não atendem a preferência do consumo nacional.

O aumento na relação comprimento/largura do grão observado no mutante oito, em relação ao cultivar original foi devido à redução na largura do grão. Já no mutante um, tal aumento foi devido a uma ligeiro aumento (não significativo) no comprimento do grão.

Tabela 13. Médias ordenadas do comprimento dos grãos beneficiados e polidos (mm).

\begin{tabular}{|c|c|c|c|}
\hline Linhagens/cultivares & Média & $5 \%$ & $1 \%$ \\
\hline Mutante 1 & 7,56 & a & $\mathbf{A}$ \\
\hline Mutante 2 & 7,33 & $\mathbf{a}$ & $\mathbf{A}$ \\
\hline Mutante 11 & 7,30 & $\mathbf{a}$ & $\mathbf{A}$ \\
\hline Mutante 13 & 7,23 & $\mathbf{a}$ & $\mathbf{A}$ \\
\hline Mutante 14 & 7,19 & a & $\mathbf{A}$ \\
\hline IAC 201 & 7,15 & $\mathbf{a}$ & $\mathbf{A}$ \\
\hline Dourado Precoce & 7,09 & $\mathbf{a}$ & $\mathbf{A}$ \\
\hline Mutante 12 & 7,06 & $\mathbf{a}$ & $\mathbf{A}$ \\
\hline Mutante 6 & 7,03 & a & $\mathbf{A}$ \\
\hline Mutante 7 & 6,95 & $\mathbf{a}$ & $\mathbf{A}$ \\
\hline Mutante 5 & 6,90 & $\mathbf{a}$ & $\mathbf{A}$ \\
\hline Mutante 4 & 6,88 & a & $\mathbf{A}$ \\
\hline Mutante 10 & 6,87 & $\mathbf{a}$ & $\mathbf{A}$ \\
\hline Mutante g & 6,86 & a & A \\
\hline Mutante 9 & 6,82 & $\mathbf{a}$ & $\mathbf{A}$ \\
\hline Mutante 3 & 6,00 & a & $\mathbf{A}$ \\
\hline
\end{tabular}

Médias seguidas por letras distintas diferem entre si ao nível de significância indicado. 
Tabela 14. Médias ordenadas da espessura dos grãos (mm).

\begin{tabular}{|c|c|c|c|}
\hline Linhagens/cultivares & Médias & $5 \%$ & $1 \%$ \\
\hline Mutante 2 & 2,05 & a & A \\
\hline Mutante 11 & 2,03 & $a b$ & $\mathrm{AB}$ \\
\hline Mutante 3 & 2,03 & $a b c$ & $\mathrm{AB}$ \\
\hline Mutante 13 & 2,02 & $a b c$ & $\mathrm{AB}$ \\
\hline Mutante 1 & 2,02 & $\mathrm{abc}$ & $\mathrm{AB}$ \\
\hline Mutante 14 & 2,00 & abcd & $\mathrm{AB}$ \\
\hline Dourado Precoce & 1,96 & bcd & $\mathrm{ABC}$ \\
\hline Mutante 8 & 1,95 & bcd & $\mathrm{BC}$ \\
\hline Mutante 12 & 1,95 & cde & $\mathrm{BC}$ \\
\hline Mutante 6 & 1,94 & de & $\mathrm{BC}$ \\
\hline Mutante 5 & 1,87 & ef & CD \\
\hline Mutante 7 & 1,84 & $\mathrm{f}$ & D \\
\hline Mutante 10 & 1,83 & f & D \\
\hline Mutante 9 & 1,83 & $\mathbf{f}$ & D \\
\hline Mutante 4 & 1,81 & $\mathbf{f}$ & D \\
\hline IAC 201 & 1,69 & g & $\mathrm{E}$ \\
\hline
\end{tabular}


Tabela 15. Médias ordenadas da relação comprimento/largura dos grãos $(\mathrm{cm})$.

\begin{tabular}{|c|c|c|c|}
\hline Linhagens/cultivares & Médias & $5 \%$ & $1 \%$ \\
\hline IAC 201 & 3,59 & a & A \\
\hline Mutante 8 & 3,04 & b & B \\
\hline Mutante 1 & 3,00 & bc & $\mathrm{BC}$ \\
\hline Mutante 12 & 2,91 & $\mathrm{~cd}$ & CD \\
\hline Mutante 6 & 2,90 & $\mathrm{~cd}$ & $\mathrm{CDE}$ \\
\hline Mutante 11 & 2,86 & de & DEF \\
\hline Dourado Precoce & 2,86 & de & DEF \\
\hline Mutante 14 & 2,85 & def & DEF \\
\hline Mutante 2 & 2,85 & def & DEF \\
\hline Mutante 3 & 2,84 & def & DEF \\
\hline Mutante 13 & 2,83 & def & DEF \\
\hline Mutante 7 & 2,79 & ef & EF \\
\hline Mutante 4 & 2,79 & ef & EF \\
\hline Mutante 9 & 2,78 & ef & $\mathbf{F}$ \\
\hline Mutante 10 & 2,77 & ef & $\mathbf{F}$ \\
\hline Mutante 5 & 2,76 & f & $\mathbf{F}$ \\
\hline
\end{tabular}




\section{CONCLUSÕES}

A análise dos dados e a interpretação dos resultados obtidos no presente trabalho permitiram concluir o seguinte:

a) As linhagens mutantes selecionadas seis, 11,12 e 14 não diferiram da variedade original Dourado Precoce em nenhuma das características estudadas, sugerindo que, causas ambientais tenham influenciado para que as mesmas fossem selecionadas como mutantes, embora não sejam.

b) $\mathrm{O}$ mutante sete mostrou ser o mais promissor pela redução na altura da planta, mantendo a maioria dos caracteres estudados inalterados, em relação a variedade original Dourado Precoce (porém, para que atenda exigência do mercado consumidor, quanto ao tipo de grão longo fino, o mesmo deve ser recombinado com genótipo que possibilite melhoria deste caráter)

c) Como resumido na Tabela 16, a azida sódica mostra eficiência mutagênica para:

- alterar bidirecionalmente os caracteres número de panícula por $\mathrm{m}^{2}$, peso de 1.000 grãos, largura e espessura dos grãos beneficiados e polidos;

- aumentar o número de perfilho por planta, número de espiguetas estéreis por panícula (indesejável) e relação comprimento/largura dos grãos beneficiados e polidos.

- diminuir a altura da planta, tamanho de panícula, número de grãos férteis por panícula e produtividade. 
Tabela 16. Apresentação sintética das médias das características estudadas, discriminados pelo teste de Tukey em relação ao Dourado

\section{Precoce.}

\begin{tabular}{|c|c|c|c|c|c|c|c|c|c|c|c|c|c|c|}
\hline Mutantes/Variedades & NPP & AP & NP & $\mathrm{CP}$ & NEGP & PEEP & PMG & $\mathbf{P}$ & $\mathrm{RE}$ & RD & CG & LG & EG & RL e G \\
\hline Mulante 1 & $2,16 \mathrm{NS}$ & $124,64 \mathrm{NS}$ & $183,50 \mathrm{NS}$ & $20,50 \mathrm{NS}$ & 80,84 ** & $11,31 \mathrm{NS}$ & 37,23 * & $5,587 \mathrm{NS}$ & $74,73 \mathrm{NS}$ & $67,64 \mathrm{NS}$ & $7,56 \mathrm{NS}$ & $2,53 \mathrm{NS}$ & $2,02 \mathrm{NS}$ & $3,00 * *$ \\
\hline Mutante 2 & $2,10 \mathrm{NS}$ & $132,34 \mathrm{NS}$ & $195,50 \mathrm{NS}$ & $22,57 \mathrm{NS}$ & $98,41 \mathrm{NS}$ & $9,70 \mathrm{NS}$ & $36,86 \mathrm{NS}$ & $5,953 \mathrm{NS}$ & $75,64 \mathrm{NS}$ & $65,75 \mathrm{NS}$ & $7,33 \mathrm{NS}$ & 2,57 * & 2,05 * & $2,85 \mathrm{NS}$ \\
\hline Mulante 3 & $1,98 \mathrm{NS}$ & $133,74 \mathrm{NS}$ & $176,00 \mathrm{NS}$ & $22,48 \mathrm{NS}$ & $101,16 \mathrm{NS}$ & $11,90 \mathrm{NS}$ & $37,52 *$ & $6,433 \mathrm{NS}$ & $74,68 \mathrm{NS}$ & $66,10 \mathrm{NS}$ & $6,00 \mathrm{NS}$ & $2,56 \mathrm{NS}$ & $2,03 \mathrm{NS}$ & $2,84 \mathrm{NS}$ \\
\hline Mulante 4 & $2,53 \mathrm{NS}$ & $106,60 * *$ & $256,00 \mathrm{NS}$ & $20,71 \mathrm{NS}$ & $84,74 *$ & $7,47 \mathrm{NS}$ & $31,16 * *$ & $5,703 \mathrm{NS}$ & $73,18 \mathrm{NS}$ & $70,30 \mathrm{NS}$ & $6,88 \mathrm{NS}$ & $2,48 \mathrm{NS}$ & $1,81 * *$ & $2,79 \mathrm{NS}$ \\
\hline Mulante 5 & $2,75 \mathrm{NS}$ & 107,70 ** & $267,50 \mathrm{NS}$ & $20,57 \mathrm{NS}$ & $80,73 * *$ & $6,17 \mathrm{NS}$ & 30,53 ** & $5,978 \mathrm{NS}$ & $74,02 \mathrm{NS}$ & $71,33 \mathrm{NS}$ & $6,90 \mathrm{NS}$ & $2,58 \mathrm{NS}$ & $1,87 *$ & 2,76 * \\
\hline Mutante 6 & $1,77 \mathrm{NS}$ & $135,90 \mathrm{NS}$ & $197,50 \mathrm{NS}$ & $21,87 \mathrm{NS}$ & $102,18 \mathrm{NS}$ & $7,96 \mathrm{NS}$ & $32,82 \mathrm{NS}$ & $6,075 \mathrm{NS}$ & $75,45 \mathrm{NS}$ & $70,01 \mathrm{NS}$ & $7,03 \mathrm{NS}$ & $2,42 \mathrm{NS}$ & $1,94 \mathrm{NS}$ & $2,90 \mathrm{NS}$ \\
\hline Mutante 7 & 2,85 * & $112,55 * *$. & $250,50 \mathrm{NS}$ & $21,43 \mathrm{NS}$ & $84,35 *$ & $4,49 \mathrm{NS}$ & 31,16 * & $6,712 \mathrm{NS}$ & $73,62 \mathrm{NS}$ & $70,80 \mathrm{NS}$ & 6,95 NS & $2,49 \mathrm{NS}$ & $1,84 * *$ & $2,79 \mathrm{NS}$ \\
\hline Mulante 8 & 2,81 * & $83,50 * *$ & $252,00 \mathrm{NS}$ & $16,75 * *$ & $49,84 * *$ & $20,05 * *$ & $29,93 * *$ & $2,883 * *$ & $72,56 \mathrm{NS}$ & $65,35 \mathrm{NS}$ & $6,86 \mathrm{NS}$ & $2,28 * *$ & $1,95 \mathrm{NS}$ & $3,04 * *$ \\
\hline Mutante 9 & $2,46 \mathrm{NS}$ & $112,00 * *$ & $246,50 \mathrm{NS}$ & 20,13 * & $79,04 * *$ & $4,69 \mathrm{NS}$ & $30,00 * *$ & $5,908 \mathrm{NS}$ & $73,38 \mathrm{NS}$ & $69,98 \mathrm{NS}$ & $6,82 \mathrm{NS}$ & $2,46 \mathrm{NS}$ & $1,83 \mathrm{NS}$ & $2,78 \mathrm{NS}$ \\
\hline Mutante 10 & $2,56 \mathrm{NS}$ & $107,60 * *$ & $260,50 \mathrm{NS}$ & $18,76^{* * *}$ & $68,42 * *$ & $6,59 \mathrm{NS}$ & $30,68 * *$ & $5,545 \mathrm{NS}$ & 73,02 NS & $70,65 \mathrm{NS}$ & $6,87 \mathrm{NS}$ & $2,48 \mathrm{NS}$ & $1,83^{* *}$ & 2,77 * \\
\hline Mutante 11 & $1,85 \mathrm{NS}$ & $137,40 \mathrm{NS}$ & $197,00 \mathrm{NS}$ & $21,83 \mathrm{NS}$ & $102,58 \mathrm{NS}$ & $6,59 \mathrm{NS}$ & $36,32 \mathrm{NS}$ & $6,862 \mathrm{NS}$ & $74,29 \mathrm{NS}$ & $65,53 \mathrm{NS}$ & $7,30 \mathrm{NS}$ & $2,53 \mathrm{NS}$ & $2,03 * *$ & $2,86 \mathrm{NS}$ \\
\hline Mutante 12 & $1,86 \mathrm{NS}$ & $137,40 \mathrm{NS}$ & $233,50 \mathrm{NS}$ & $21,80 \mathrm{NS}$ & $100,39 \mathrm{NS}$ & $6,03 \mathrm{NS}$ & $32,84 \mathrm{NS}$ & 6,553 NS & $74,59 \mathrm{NS}$ & $68,38 \mathrm{NS}$ & $7,06 \mathrm{NS}$ & $2,43 \mathrm{NS}$ & 1,95 NS & $2,91 \mathrm{NS}$ \\
\hline Mutente 13 & $2,16 \mathrm{NS}$ & $128,25 \mathrm{NS}$ & $165,50 \mathrm{NS}$ & $20,66 \mathrm{NS}$ & $89,20 \mathrm{NS}$ & $11,61 \mathrm{NS}$ & $37,28 *$ & $5,275 \mathrm{NS}$ & $75,28 \mathrm{NS}$ & $66,23 \mathrm{NS}$ & $7,23 \mathrm{NS}$ & $2,55 \mathrm{NS}$ & $2,02 \mathrm{NS}$ & $2,83 \mathrm{NS}$ \\
\hline Mutante 14 & $1,87 \mathrm{NS}$ & $137,89 \mathrm{NS}$ & 208,00 NS & $22,18 \mathrm{NS}$ & $102,12 \mathrm{NS}$ & $7,21 \mathrm{NS}$ & $34,87 \mathrm{NS}$ & $6,350 \mathrm{NS}$ & $75,63 \mathrm{NS}$ & $68,02 \mathrm{NS}$ & $7,19 \mathrm{NS}$ & $2,52 \mathrm{NS}$ & $2,00 \mathrm{NS}$ & $2,85 \mathrm{NS}$ \\
\hline Dourado Precoce & $1,99 \mathrm{NS}$ & $135,84 \mathrm{NS}$ & $195,50 \mathrm{NS}$ & $23,00 \mathrm{NS}$ & $114,84 \mathrm{NS}$ & $6,70 \mathrm{NS}$ & $34,36 \mathrm{NS}$ & $6,278 \mathrm{NS}$ & $74,31 \mathrm{NS}$ & $67,17 \mathrm{NS}$ & $7,09 \mathrm{NS}$ & $2,48 \mathrm{NS}$ & $1,96 \mathrm{NS}$ & $2,86 \mathrm{NS}$ \\
\hline IAC 201 & $2,25 \mathrm{NS}$ & $119,94 * *$ & $194,50 \mathrm{NS}$ & $23,11 \mathrm{NS}$ & $169,53 * *$ & $6,58 \mathrm{NS}$ & $24,21 * *$ & $6,217 \mathrm{NS}$ & 72,94 NS & $65,06 \mathrm{NS}$ & $7,15 \mathrm{NS}$ & 1,97 ** & $1,69 * *$ & $3,59 * *$ \\
\hline
\end{tabular}

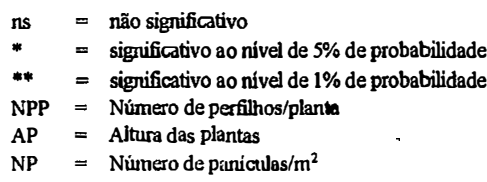

$\begin{array}{ll}\text { CP } & =\text { Comprimento das pariculas } \\ \text { NEGP } & =\text { Número de grãos/panicula } \\ \text { PEEP } & =\text { Porcentagem de espiguetas estéreis/panicula } \\ \text { PMG } & =\text { Peso de } 1.000 \text { grãos } \\ \text { P } & =\text { Produtividade } \\ \text { CG } & =\text { Comprimento dos grãos }\end{array}$

LG $=$ Largura dos grãos

EG $=$ Espessura dos grãos

RL e $G=$ Relação comprimento/argura dos grãos

$\begin{array}{ll}\mathrm{RE} & =\text { Renda } \\ \mathrm{RD} & =\text { Rendimento }\end{array}$ 


\section{REFERÊNCIAS BIBLIOGRÁFICAS}

ANDO, A. Indução de mutaçao em arroz por meio de radiação gama, combinada com protetores químicos e compostos alquilantes. Relatório Científico do Departamento e Instituto de Genética, Piracicaba, 6: 8-12, 1972.

ANDO, A. Seleção de mutantes dos tratamentos combinados com raios-gama, glutatione e EMS ou EI. Relatório Científico do Departarnento e Instituto de Genética, Piracicaba, 7: 7-9, 1973.

ANUÁRIO ESTATÍSTICO BRASILEIRO. 1978-1992.

ANGLADETTE, A. El Arroz. Barcelona, Blume, 1968. 867p.

AZZINI, L.E.; BASTOS, C.R.; VILLELA, O.V.; GALLO, P.B.; SOAVE, J.; CASTRO, L.H.S.M. de.; TISSELLI FILHO, O. Melhoramento do arroz: I. Comportamento de cultivares e linhagens de arroz irrigado no Estado de São Paulo em 1990/91 e 1991/92. Bragantia, Campinas, 1995. (no prelo)

BASTOS, C.R.; AZZINI, L.E.; CAMARGO, C.E.O.; POMPEU, C.V.; CHIAVEGATO, E.J.; DALL'ORTO, F.A.C.; NAGAI, H.; FAZUOLI, L.C.; GODOY, I.J. \& VEIGA, R.F.A. Descritores Mínimos para o Registro Institucional de variedades: Arroz. Documento IAC 45, Campinas, 1994. 9p. 
BHIVARE, L.N. \& DAS, P.K. Isolation and evaluation of some of the promissing mutants of paddy. Journal of Nuclear Agriculture and Biology, Sindri, 9(3): $106,1980$.

BLUM, A. Evidence for genetic variability in drought resistance and its implications for plant breeding. In: IRRI. Drought resistance in crop with emphasis on rice. Manila. IRRI, 1982. p.53-68.

BORAH, S.P. \& GOSWAMI, B.C. A superfine grain mutant induced in rice. Journal of Nuclear Agriculture and Biolocjy, sindri, 10(1): 6-8, 1981.

BRASIL, Ministérío da Agricultura. Regras para Análise de Sementes. Brasília, Departamento Nacional de Produção vegetal, 1992. 365p.

CARMONA, P.S.; PEDROSO, B.A.; REGINATTO, M.P.V.; DA SILVA, J.C.; MARIOT, C.; KEMPF, D.; VALÉRIO, M. G.B. Melhoramento Genético de arroz irrigado. In: REUNIAO DA CULTURA DO ARROZ IRRIGADO, 10, Porto Alegre, 1980. Anais. p.11-14.

CHANDRARATNA, M. F. Genetics and breeding of rice. London, Longmans Green, 1964. 389p.

DALRYMPLE, D.G. Development and spread of high-yielding varieties of wheat an rice in the less developed nations. Foreign Agricultural Economic Report, USDA. N' 95, 120 p., 1976.

DWIVEDI, S.L.; RAI, K.N.; SINGH, R.B. Manifold morphological effects of induced dwarfism in rice (Oryza sativa L.) . Current Science, Bangalore, 48(12): 541, 1979.

EGGUM, B.O. The nutritional value of rice $\ln$ comparison with other cereals. In: Proceeding of the workhop on chemical aspects of rice grain quality.Los Banños, 1979. p.91-11. 
EMBRAPA. Manual de métodos de pesquisa em arroz $1^{a}$ Aproximação. Centro Nacional de Pesquisa de Arroz e Feijão. Goiânia, 1977. 106p.

FAO/IAEA. Mutant varieties. DATA BANK. Mutation Breeding Newlwtter. (38):18, Dec.1991.

FORNASIERI FILHO, D. \& FORNASIERI, J.L. Manual da cultura do arroz. Jaboticabal, UNESP/FUNEP, 1993. 221p.

GERMEK, E. \& BANZATTO, N.V. Melhoramento do arroz no Instituto Agronômico de Campinas. Boletim Técnico Instituto Agronômico, Campinas, (202):56, fev. 1972.

GOMES, F.P. Estatística Moderna na Pesquisa Agropecuária. Associação Brasileira para Pesquisa Agropecuária da Potassa e Fosfato, Piracicaba, Ed. Nagy, 1984. 160p.

GOVINDASWAMI, S.; GHOSH, A.K.; MISRA, R.N. Improvement in quality characteristic and yield attributes through gamma-irradiation in rice (oryza sativa L.) Indian Journal Agricultura Science, Delhi, 42(10): 869-72, 1972.

GRIST, D.H. Rice Longmans groups, 1965. 548p.

GUIMARĀES, E.P. Qualidade de grão de arroz. In: REUNIAO DA COMISSAO TÉCNICA DE ARROZ DA REGIAO. Campinas, 1989. p. 13

INTERNATIONAL RICE RESEARCH INSTITUTE Annual report. Los Baños, Laguna, Philippines. 1978. p.6-10.

INTERNATIONAL RICE RESEARCH INSTITUTE, Annual report. Los Baños, Laguna, Philippines. 1979. p.20-21.

JENNINGS, P.R. Plant type as a rice breeding objetive. Crop Science, Madison, 4: 13-5, 1964.

JENNINGS, P.R. The evolution of plant type in Oryza sativa.Economic Botany, New York, 20: 398-402, 1966. 
JENNINGS, P.R.; COFFMAN, W.R.; KAUFFAMN, H.E. Rice in improvement, Manila, IRRI, 1979. 186p.

KAWAI, T. Genetics studies on short-grain mutants in rice. In: Mutations in plant breeding. II. Proceedings of a panel on co-ordination of research on the use of induced mutations in plant breeding, IAEA. Viena, 161-1 Apud Plant breeding abstracts, 39: 282, 1968. (Resumo)

KERSTING, E.L.; OLIVEIRA, M.A.; CRUZ, O.C. conheça as variedades. Lavoura Arrozeira, Porto Alegre, 29 (295):5-6, 1976.

MAHADEVAPPA, M.; IKEHASHI, H.; NOORSHYAMSI, H.; W.R. COFFMAN, 1981. Improvement of native rices through induced mutation. IRRI Research Paper Serie, Manila 57: 7 p., 1981.

MIAH, A.J. \& BHATTI, I.M. Evolution of new rice varieties by Lnduced mutations to increase yield and resistance to diseases and to improve seed quality. In: Rice breeding with induced mutations. 86: 75-96. Tech. Rep. Serv. IAEA, Viena 83: 75-96., 1968.

MIAH, A.J.; MANSUR, M.A.; JALALUDDIN, M. Improvement of rice through induced mutations. Indian Journal Agricultural Science, Delhi 51 (3): 145, 1981.

MINISTÉRIO DA AGRICULTURA. Norma de identidade, qualidade embalagem e apresentação do arroz. Brasília, 1988. 25p.

NANDA, J.S. \& COFFMAN, W.R. IRRI's Efforts to improve the protein content of rice. In: Workshop on chemical aspects of grain quality. Los Baños, 1-20., 1978.

NAVASERO, S.A. \& TANAKA, A. Low-light induced death of lower leaves of rice and its effectf on grain yield. Plant and Soil, Hague, 24 (3) : 17-31, 1966. 
NOLDIN, J.A.; MARQUES, L.F; MOREL, D.A.; ISHITY, T. Competição regional de cultivares e linhagens de arroz irrigado em Santa Catarina. In: REUNIAO DA CULTURA DO ARROZ IRRIGADO, 11. Pelotas, 1981. Anais. Pelotas, RS, 1981. p.75-6.

PEDROSO, B.A.; CARMONA, P.S.; GONÇALO, J.F.P.; REGINATTO, M.P.V.; RIBEIRO, A.S.; GASTAL, F.L.C. Melhoramento genético do arroz. In: REUNIAO DA CULTURA DO ARROZ, 7. 1977. Anais. Porto Alegre, RS. p.317

PEDROSO, B.A. \& SILVA, J.C. da. Competição de cultivares de arroz de sequeiro. In: REUNIAO DA CULTURA DO ARROZ IRRIGADO, 11. 1981. Anais. Pelotas, RS. p.95-97

RANGEL, P.H.N. Eficiência da seleção simultânea de arroz (Oryza sativa L.) em várzea com e sem irrigação controlada. Piracicaba, 1990. 128p. (Doutorado - Escola Superior de Agricultura "Luiz de Queiroz"/USP).

REE, J.H. Rice breeding problems in Korea. In: Rice breedlng with induced mutations, Tech. Rep. Ser. IAEA, Viena. 86: 119-125, 1968.

RUTGER, J.N. Short stature, early maturing rice mutants. Mutation Breeding Newsletter, Viena, (10):6-7, 1977.

SARALA, A.K. \& REDDY, G.M. Role of local germplasm and induced mutation in the improvement of the protein content in rice. Theoretical Applied Gentics India, 54(2):75-9, 1979.

SHARMA, D. \& LAL, G. S. Parental genotypes and induced genetic variability in rice. Indian Journal Agricultural àcience, Delhi, 51(7):471-4, 1981.

SIGURBJORNSSON, B. \& MICKE, A. Progress in mutation breeding. In: Induced mutation in plants. Proceedings of a symposium CL jointhy organizei by the IAEA and FAO and he Pullman, Washington. 673-697. Apud: Plant Breeding Abstracts, 40: 481, 1969. 
SILVA, M.V. da. A cultura do arroz. Lisboa, 1975. p.32-37

SILVA, P.D. da. Sistema de produção para as variedades de arroz de porte moderno. Lavoura Arrozeira, Porto Alegre, 29(296): 50-2, 1976.

SILVA, J.C. da; CARMONA, P.S.; REGINATTO, M.P.V.; KEMPT, D. Ensaios de redimento. In: REUNIÃO DA CULTURA DO ARROZ IRRIGADO, 10. 1980. Anais. Porto Alegre, RS. p.31-34

SOARES, A.A.; REIS, M.S.; SOARES, P.C. Caipó, nova opção de arroz de sequeiro para Minas Gerais, Revista Cesres, 231-17,1993.

SOUZA, D.M.; LEITÃO FILHO, H.F.; BANZATTO, N.V.; SUGIMORI, M.H. Caracterização de cultivares de arroz (Oryza sativa L.). Bragantia, Campinas, 31:207-14, 1972.

SRINIVAS, T. \& BHASHYAM, M.K. Effect of variety environment of milling quality of rice. In: INTERNATIONAL RICE RESEARCH INSTITUTE. Rice graín cjuality and marketing. IRRI, Manila, 1985. p. 49-59.

TANAKA, S. Radiation-induced mutations in rice: An analys is of mutations induced by chronic gamma-ray exposure. In: Rice breeding with induced mutations. Tech. Rep. Ser. IAEA, Viena. 86:53-64, 1968.

TISSELLI FILHO, 0. \& AZZINI, L.E. Instruções Agrícolas para o Estado de São Paulo. Boletim Técnico-Instituto Agronômico, Campinas, 200:29 set. 1990. 